\title{
Crustal anatexis and evolution of granitoid magma in Permian intra-oceanic island arc, the Asago body of the Yakuno ophiolite, Southwest Japan
}

\author{
Yoshimitsu SuDA \\ Department of Earth and Planetary Systems Science, Graduate School of Science, \\ Hiroshima University, Higashi-Hiroshima 739-8526, Japan
}

\begin{abstract}
A late Paleozoic crustal section of an intra-oceanic island arc occurs in the Middle Unit (M-Unit) of the Asago body from the Yakuno ophiolite, SW Japan. It consists of mafic metamorphic rocks and felsic to mafic later intrusions. The M-Unit is composed of three lithologic zones: the Lower migmatite zone (L-MZ), the Middle metagabbro zone (M-MZ), and the Upper amphibolite zone (U-AZ). The metamorphic grade of the lowest horizon of the $\mathrm{M}-$ Unit reaches granulite-facies conditions $\left(\mathrm{P}=3.5-5.5 \mathrm{kbar}\right.$ at $\left.\mathrm{T}=850-860^{\circ} \mathrm{C}\right)$ and an assemblage of plagioclase + clinopyroxene + orthopyroxene (pseudomorph) + hornblende (tschermakite or magnesiohastingsite) appears in the mafic metamorphic rocks. Structural relationships of the migmatite and related rocks suggest that a small-scale leucosome (i.e. melt) was generated at the bottom of L-MZ and its upward melt segregation led to the formation of medium- to large-scale plutons and dykes of later intrusions into the $\mathrm{M}^{-} \mathrm{MZ}$ and $\mathrm{U}-\mathrm{AZ}$. The bulk rock chemistry of these rocks suggests that the later intrusions were derived from the partial melting of mafic metamorphic rocks, leaving melanosome as residuum. Major and trace element compositional variation of the later intrusions indicates that the leucosome $\left(\mathrm{SiO}_{2} 48-71 \mathrm{wt} \%\right)$ may be a source of the plutons and dykes of medium-silica content $\left(\mathrm{SiO}_{2}\right.$ 52-67 wt\%), whereas chemical compositions of the plutons and dykes of high-silica content $\left(\mathrm{SiO}_{2} 72-76 \mathrm{wt} \%\right)$ and those of the leucosomes do not overlap. The fact indicate that the plutons and dykes of high-silica content may have been derived from either compositionally more differentiated magma or a completely exotic one.
\end{abstract}

\section{Introduction}

The petrogenesis of granitoid in the intra-oceanic island arc (OIA) is the key to constraining the process of continental crust growth by accretion of the oceanic island arc (e.g. Taira et al., 1992). Different models have been proposed for the generation of intermediate to felsic magmas in OIA: (1) Differentiation of high-Mg andesite or basaltic magma derived from the partial melting of the upper mantle (e.g. Meijer, 1983; Shirey and Hanson, 1984; Stern and Hanson, 1991; Haragchi et al., 2003); (2) Partial melting of subducting oceanic crust (e.g. Martin, 1986; 1987; 1993; Nelson and Forsythe, 1989; Defant and Drummond, 1990; Drummond et al., 1996); and, (3) Anatexis of mafic lower crust (e.g. Atherton and Petford, 1993; Kay and Kay, 1993; Kawate and Arima, 1998). Many experiments indicate that partial melting of amphibolite is the most effective process to generate a large

Y. Suda, cs504015@scs.kyushu-u.ac.jp Corresponding author volume of intermediate to felsic melts (e.g. Beard and Lofgren, 1991; Wolf and Wyllie, 1994; Nakajima and Arima, 1998). Therefore, the anatexis of mafic lower crust and/or the partial melting of subducting oceanic crust have been though to be the most important mechanisms for the genesis of granitoid magma in the OIA (Beard, 1995).

The mafic migmatite and related granitoid occur in the Middle Unit of the Asago body from the Late Paleozoic Yakuno ophiolite, SW Japan. This unit has been considered to be a lower to middle crustal section of an OIA setting (e.g. Hayasaka, 1991). The migmatite zone of the unit records morphologic and lithologic changes at the lower crustal level. Findings of granulite-facies minerals of clinopyroxene and pseudomorphs of orthopyroxene in some mafic metamorphic rocks, constrain not only the petrogenesis of granitoid in the OIA but also the magmatic process of mafic lower crust. In this paper, the author describes the morphologic and structural relationships of the mafic migmatite together with petrologic 
data, and discusses the process to generate the granitoid magma in an OIA setting.

\section{Geologic setting}

The Yakuno ophiolite is a Late Paleozoic metamorphosed mafic complex with minor ultramafic and felsic rocks in the Maizuru Terrane of Southwest Japan (Fig. 1a). At least three different segments have been recognized ac- cording to their petrogenetic features: (1) an unusually thick oceanic crust-mantle section; (2) island arc type crust; and, (3) back-arc basin oceanic crust as a basement of the Permian Maizuru Group (Ishiwatari, 1985, 1999; Koide, 1986; Hayasaka, 1990; Ishiwatari et al, 1990; Ichiyama and Ishiwatari, 2003). The Asago body, 10-13 km in size, occurs as a fault-bounded slice that tectonically overlays the Late Permian accretionary complex of the Ultra-Tanba Terrane (Fig. 1b). The body consists of three

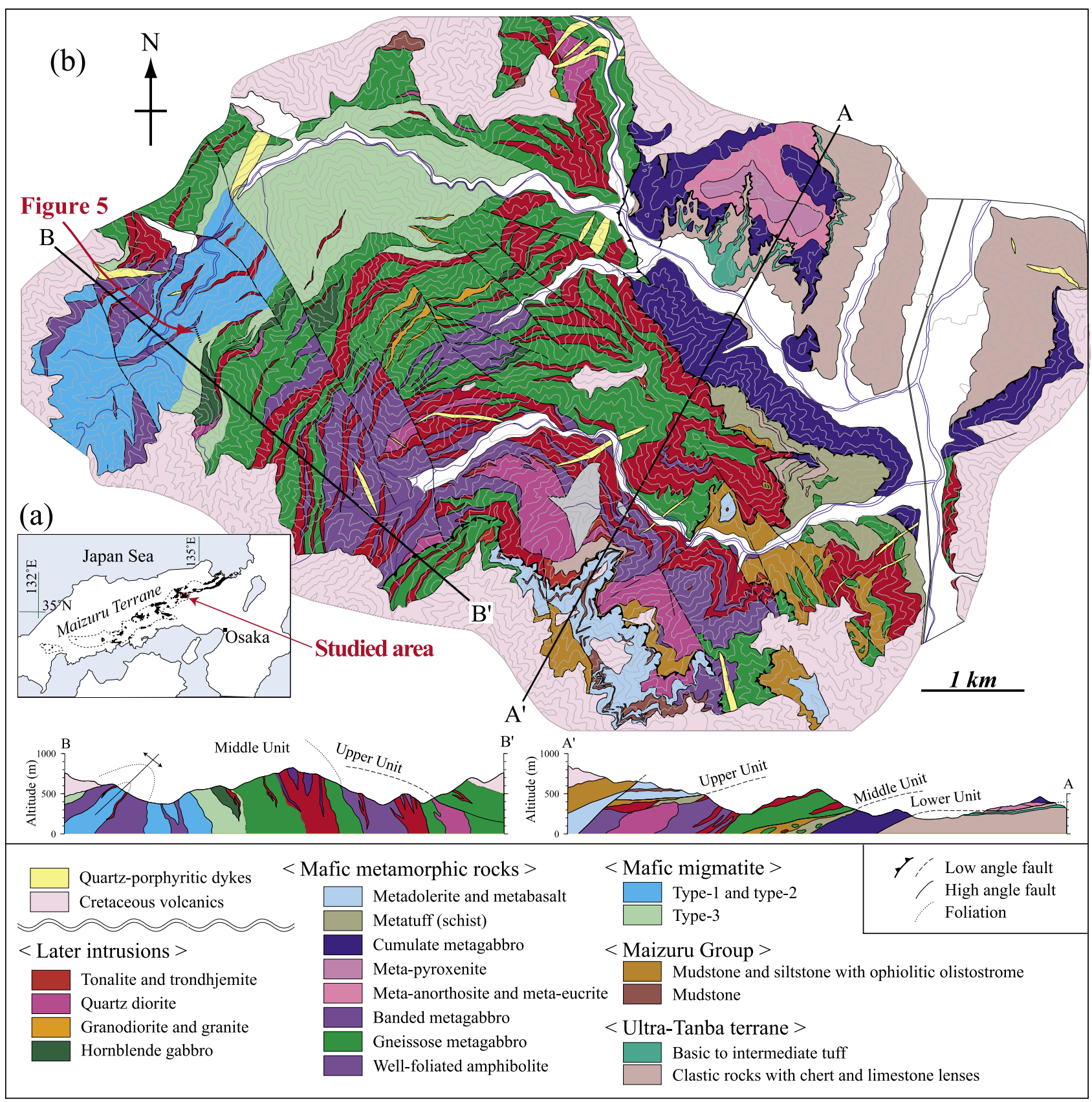

Figure 1. (a) Index map showing the distribution of the Yakuno igneous complex (black) in the Maizuru Terrane, Southwest Japan, and (b) geological map and its cross sections of the Asago body of the Yakuno igneous complex. Modified from Hayasaka et al. (1996). The traverse lines $\left(\mathrm{A}^{-} \mathrm{A}^{\prime}\right.$ and $\left.\mathrm{B}^{-} \mathrm{B}^{\prime}\right)$ of the cross sections are indicated on the geological map. 
major structural units: the Lower Unit (L-Unit), Middle Unit (M-Unit) and Upper Unit (U-Unit). Each of these units is bounded by a low angle fault (Hayasaka, 1990).

The L-Unit (oceanic crust with T-MORB affinity), consisting mainly of mafic-ultramafic metamorphic cumulates, is presumed to be derived from the lower oceanic crust to the upper mantle (Hayasaka et al., 1996). Metagabbro in the L-Unit, and that from Fukuchiyama area, about $30 \mathrm{~km}$ away from the Asago area, have yielded Sm-Nd whole rock-clinopyroxene-plagioclase internal isochron ages of $343 \mathrm{Ma}$ and $341 \mathrm{Ma}$, respectively (Hayasaka et al., 1996). These ages could represent the formation of the original oceanic crust.

The $3.0 \mathrm{~km}$-thick M-Unit, principally described in this paper, consists of deformed mafic metamorphic rocks, and deformed / undeformed felsic to mafic later intrusions. $35 \%$ of the area covered by the M-Unit is occupied by the later intrusions, and the remainders are the mafic metamorphic rocks. Zircon separated from two samples of massive and strongly mylonitized trondhjemite of the M-Unit have yielded $\mathrm{U}-\mathrm{Pb}$ ages of $282 \mathrm{Ma}$ and $285 \mathrm{Ma}$, respectively (Herzig et al., 1997). This result indicates that the magmatism and the deformation of the later intrusions occurred simultaneously during the early Permian age. $\mathrm{K}$-Ar ages of metamorphic amphiboles from the Yakuno complex form a cluster of ages around $260 \pm 10 \mathrm{Ma}$, which may indicate the latest stage of deformation-metamorphic events associated with the emplacement of the Yakuno ophiolite (Hayasaka, 1990).

Hayasaka (1990) described the U-Unit as consisting of metagabbro, tonalite, metadolerite, metabasalt and massive mudstone. The metabasalt and mudstone are conformably interbedded with each other. Such an occurrence is also observed in the Lower Formation of the Permian Maizuru Group, located to the northwest of the Asago body. Basalt from the Maizuru Group shows geochemical affinity with basalt from the back-arc basin (Koide, 1986). The basement complex of the Maizuru Group have yielded $\mathrm{Rb}^{-} \mathrm{Sr}$ whole rock isochron ages of $281 \mathrm{Ma}$ and $290 \mathrm{Ma}$ (Koide et al., 1987).

Hayasaka et al. (1996) summarized the geotectonic history of the Asago body as follows: Oceanic crust was formed during the Early Carboniferous. This was subsequently brought to the island arc setting during the Permian age, which resulted in the formation of the igneous rocks of the later intrusions. The island arc collided to a continent during the Late Permian, which resulted in the formation of an ophiolitic nappe pile of the three different origins.

\section{Structure and petrography of the $M-$ Unit}

\section{Mafic metamorphic rocks}

The mafic metamorphic rocks consist mainly of metagabbros and well-foliated amphibolite, which show various degrees of deformation and metamorphic textures; gneissosity with preferred orientation of constituent minerals. The metagabbros, conserve (more or less) their igneous textures, such as the poikilitic texture of hornblende. Their protoliths, gabbroic rocks, were identified from these textures. On the other hand, the protoliths of "wellfoliated amphibolite" strongly show foliation and lineation and thus cannot be uniquely determined from the field occurrence and texture. Gneissose metagabbro gradually changes into the amphibolite in the upper part of the M-Unit (Fig. 2). Light- and dark-colored metagabbro layers alternate at a scale of several millimeters to several centimeters to form banded metagabbro, which occurs only in the lowermost part of the M-Unit (Fig. 2). The light-colored layers are composed of a plagioclase (saussurite) + clinopyroxene mineral assemblage with a distinct preferred orientation, whereas the dark-colored layer consists of the granulite-facies mineral assemblage described below.

In the lowermost part of the M-Unit in Figure 2 (T1-Z and T2-Z), metagabbro is characterized by a hornblende granulite facies mineral assemblage, plagioclase + clinopyroxene + orthopyroxene + hornblende \pm quartz (i.e. granulite facies metagabbro). However, all of the orthopyroxene crystals have been altered into serpentine and chlorite (i.e. bastite), and the plagioclase has been moderately saussuritized due to hydrothermal alteration. The amount of pyroxene in the rocks decreases with increasing a structural level, at the same time, the mineral paragenesis changes into plagioclase \pm clinopyroxene + hornblende \pm quartz, indicating amphibolite facies conditions (i.e. amphibolite facies metagabbro). Apatite commonly occurs in the metagabbro as an accessory mineral with minor amounts of ilmenite and titanite. Well-foliated amphibolite occurs in the upper part of the M-Unit, composed of plagioclase + hornblende with a distinct lattice preferred orientation

\section{Later intrusions}

The later intrusions occur as several tens of meters- to kilometers-scale plutons and several centimeters- to meters-scale dykes in the middle to upper part of the $\mathrm{M}^{-}$ Unit (Fig. 2). Several centimeters-scale leucosome, described below, are also present in the lower part of the $\mathrm{M}^{-}$ Unit in Figure 2 (Migmatite zone). As noted above, mag- 


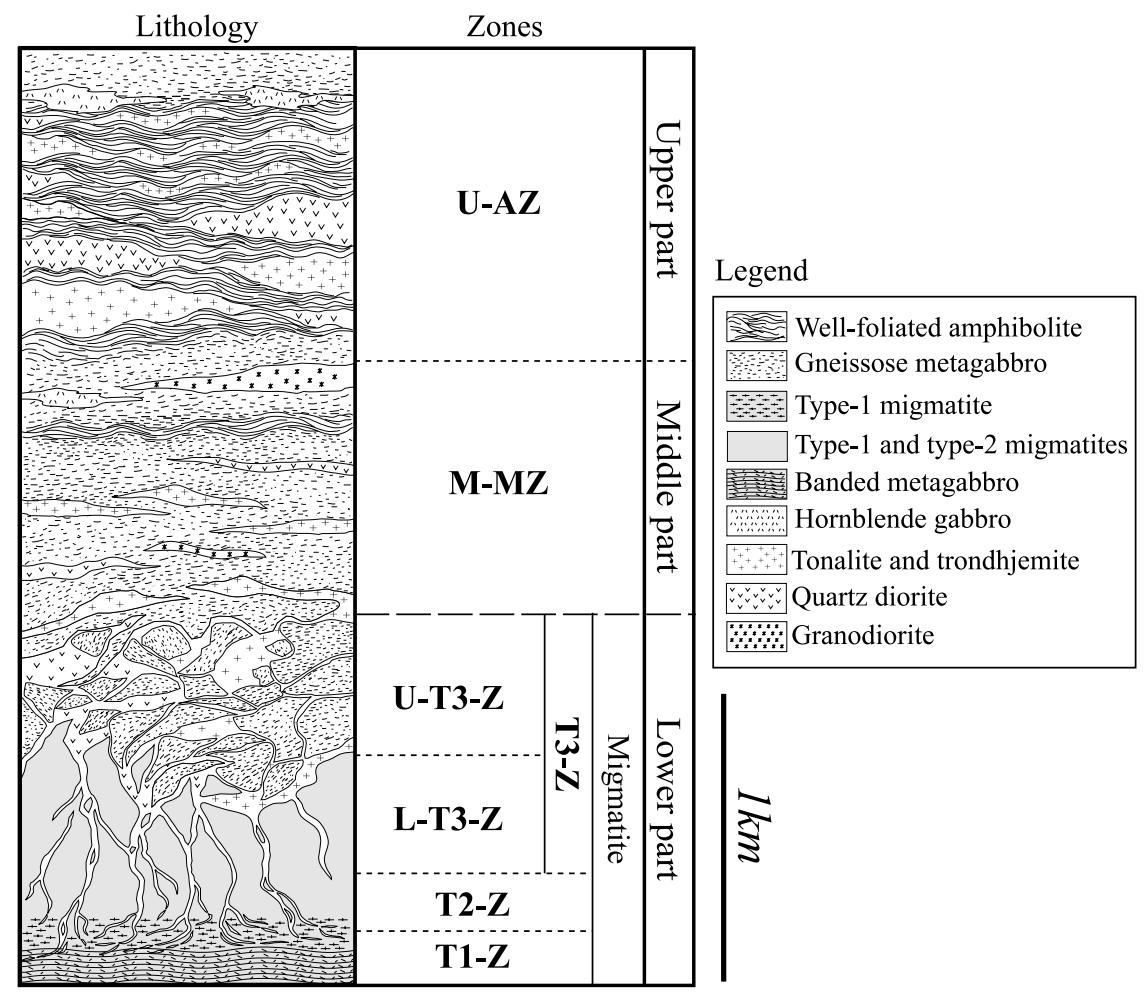

Figure 2. Schematic columnar section of the Middle Unit in the Asago body. Abbreviations: U-AZ, upper amphibolite zone; $\mathrm{M}-\mathrm{MZ}$, middle metagabbro zone; T3-Z, type-3 zone; U-T3-Z, upper half of type-3 zone; $L-T 3-Z$, lower half of type-3 zone; T2-Z, type-2 zone; T1-Z, type- 1 zone.

matic emplacement and deformation of the later intrusions occurred simultaneously. Though deformation is stronger in the mafic metamorphic rock, the later intrusions also underwent deformation that generated a mylonitic structure. The later intrusions are emplaced discordantly with the pre-existing gneissosity of the country mafic metamorphic rocks. However, subsequently formed gneissosity of the plutons is concordant with that of the host mafic metamorphic rocks.

The later intrusions are composed of various types of mafic, intermediate and felsic igneous rocks such as hornblende gabbro and granitoid. The granitoid range from quartz diorite and quartz monzodiorite through tonalite and trondhjemite to granodiorite and granite. They are composed of plagioclase \pm clinopyroxene + hornblende + $\mathrm{K}$-feldspar + quartz + biotite (partly chloritized) with subordinate ilmenite, titanite, apatite and zircon. Clinopyroxene predominantly occurs in the lowermost part of the M-Unit in Figure 2 (T1-Z). On the other hand, the hornblende gabbro is composed of plagioclase + hornblende + biotite (partly chloritized) with subordinate apatite. Areal fractions according to the rock types of the later intrusions were estimated from the geological map. Tonalite and trondhjemite, quartz diorite, and others constitute $75 \%, 20 \%$ and $5 \%$ of the total area of the later intrusions, respectively.

\section{Migmatite}

Migmatite occur in the lower part of the M-Unit in Figure 2 (Migmatite zone). They consist of macroscopic composite rocks of the mafic metamorphic rocks and the later intrusions (Fig. 3). Hornblendite sometimes occurs, forming the darkest part in the migmatite. In this study, the mafic metamorphic rocks suite is called mesosome, the later intrusions suite is called leucosome, and the hornblendite suite is called melanosome according to the definitions by Wimmenauer and Bryhni (2002). The structures of migmatite in the M-Unit systematically change with the metamorphic grade and the structural level. Based on the variation of structures, the migmatite are divided into three types: type- 1 , type- 2 and type-3, whose distributions are accordance with their structural level: type-1 zone (T1-Z), type-2 zone T2-Z and type-3 zone (T3-Z) in increasing order of structural level (Fig. 2). In many cases, the contacts between these three types are gradational.

Type-1

Type-1 (migmatite) composes the lowermost part of the $M-$ Unit together with the banded metagabbro, named the T1-Z (Fig. 2). The type-1 can be called metatexite (Brown, 1973; Sawyer, 1996; Milord et al., 2001), in which most of the pre-migmatization structures, banded or gneissose structure of metagabbros, survived during 

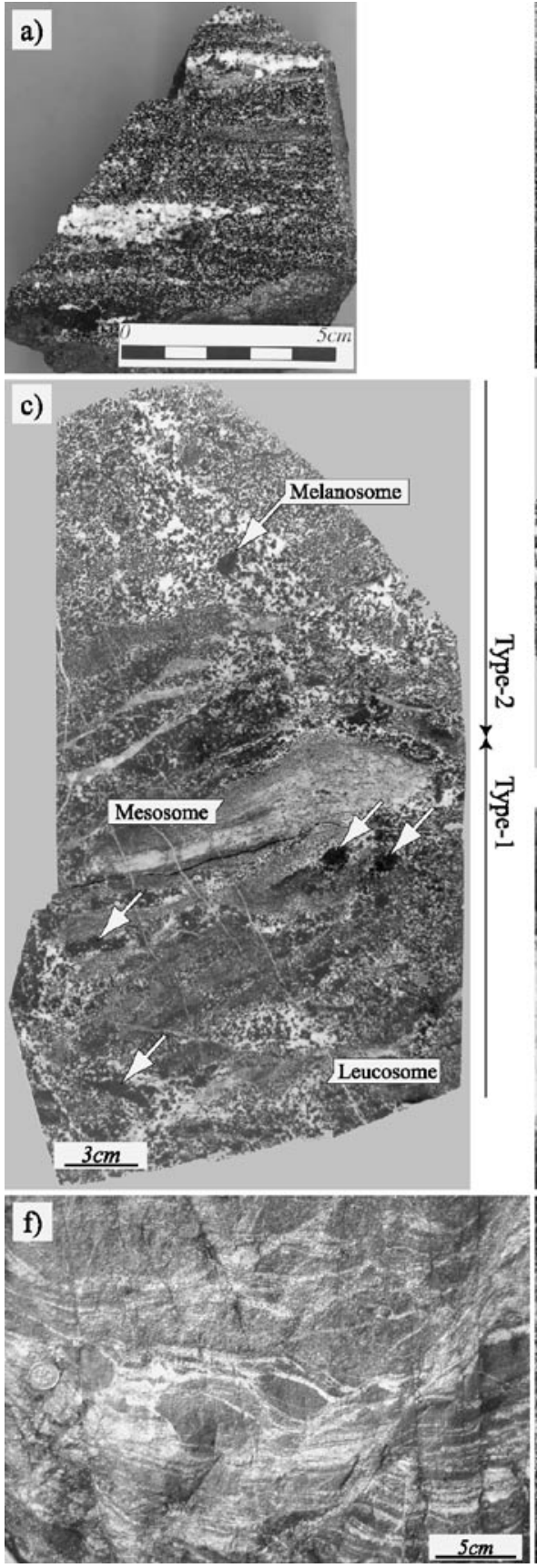
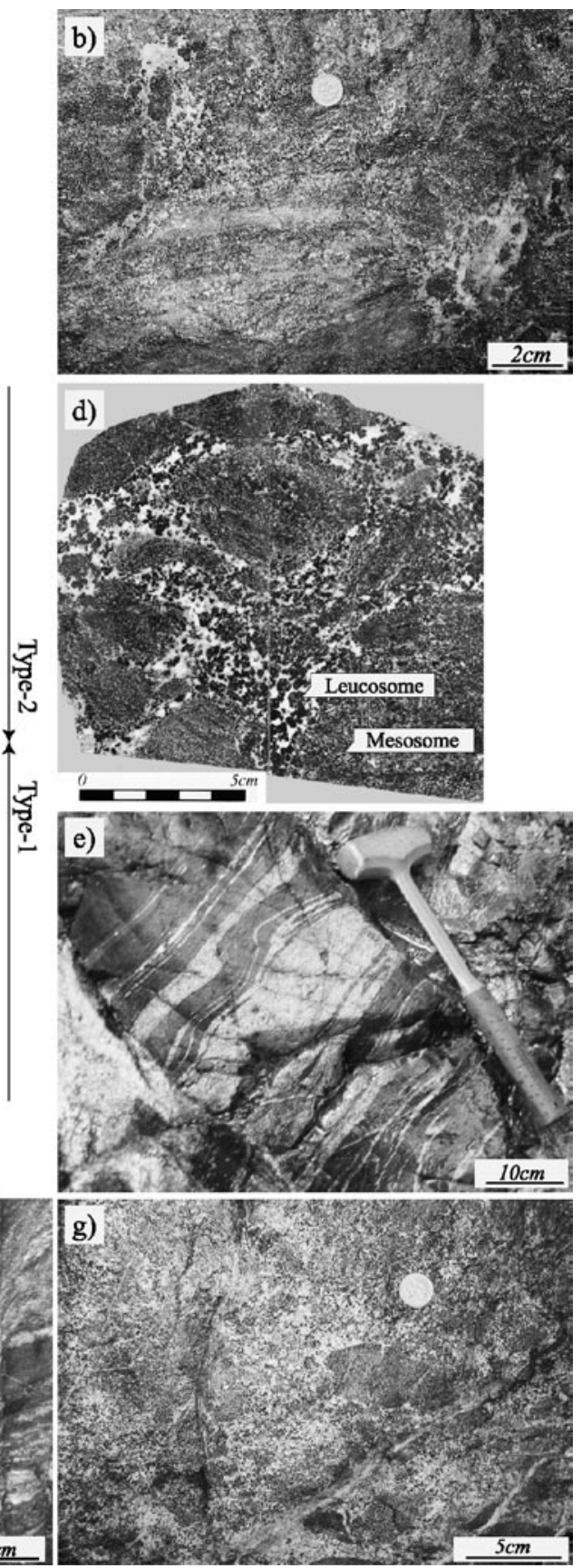

Figure 3. Photographs showing the variety of structures in a migmatite: (a) type-1; stromatic structure, lenticular leucosome bearing type, (b) type-1; dilation structure, symmetric foliation boudinage type, (c) type-1 and type-2; field relationship, (d) type-2, nebulite like structure, (e) type-3; folded and layered structure, (f) type- 3 ; boudin and layered structure and $(\mathrm{g})$ type- 3 ; schollen structure. (a), (c) and (d) polished surface, (b), (e), (f) and (g) field appearances. Arrows in (c) pointing to melanosomes. partial melting, and their appearances suggest that leucosomes formed from the in-situ anatectic melt (Fig. 3a-c). Structures of the type-1 can be divided into three types from the appearance of leucosome: (1) stromatic structure, (2) diktyonitic structure and (3) dilation structure (Mehert, 1968; McLellan, 1988). Type-1 with stromatic structure can be called non-segregated migmatite (Sawyer, 1991). Leucosome in this structure forms either layered or lenticular (Fig. 3a) shapes, which are intercalated parallel to the foliation or gneissosity of the banded metagabbro. On the other hand, the type-1 with dilation and dik- tyonitic structures can be called segregated migmatite (Sawyer, 1991). Leucosome in the diktyonitic structure forms a continuous network of veins, and often cuts the foliation or gneissosity of the metagabbros. The dilation structure is furthermore divided into two types: symmetric foliation-boudinage type (Fig. 3b) and asymmetric foliation-boudinage type (Platt and Vissers, 1980). Leucosome in both dilation types forms a pool, and crosscuts the foliation or gneissosity of the mesosome. Melanosome randomly occurs within leucosomes, forming the irregular rounded masses several centimeters to tens of 
centimeter in length (Fig. 3c).

Type-2

Type-2 (migmatite) occurs in a horizon overlying the T1$Z$ named the T2- $Z$ (Fig. 2). The contact between the T1$\mathrm{Z}$ and $\mathrm{T} 2-\mathrm{Z}$ is unclear, where leucosome in type- 1 is connected to that in type-2 (Fig. 3c). The type-2 can be called diatexite from their appearances (Brown, 1973; Sawyer, 1996; Milord et al., 2001), where the boundary between leucosome and mesosome or melanosome is characteristically unclear, and a homogenization and coarsening of texture occurs, forming the schlieren-like or nebulite-like structure (Mehert, 1968) (Fig. 3c, d). The type-2 is composed of larger amount of leucosome ( $>c a$. $40 \%$ ) than that in the type-1, in which pre-migmatization structures are more or less destroyed. Mesosome shows a small-scale ellipsoidal shape several centimeters in lengths, which is randomly oriented within the leucosome (Fig. 3d). Melanosome occurs at random in the leucosome, forming small patches one or two centimeters in length (Fig. 3c).

\section{Type -3}

Type-3 (migmatite) occurs in a horizon overlying the T2$\mathrm{Z}$ named T3-Z (Fig. 2). The type-3 is generally called melt- (leucosome-) enriched migmatite, which are characterized by a clear boundary between leucosome and melanosome or mesosome (Fig. 3e-g). These appearances suggest that leucosomes in the type- 3 formed by the intrusion of externally derived melt, indicating that either large-scale melt flow or melt accumulation occurred in this zone. The structures of the type- 3 are divided into five types, forming stromatic or layered (Fig. 3e, f), folded (Fig. 3e), boudin (Fig. 3f), schollen (Fig. 3g) and agmatitic structures (Mehert, 1968; McLellan, 1988). The stromatic structure indicate the rocks in which the layers of mesosome and leucosome alternate at a relatively smallscale of less than five centimeters (McLellan, 1988). Medium- $^{-}$to large-scale alternation of the layers is called layered structure. The schollen structure predominantly occurs in the lower half of the T3-Z named the L-T3-Z (Fig. 2). Various types of migmatite structures, such as stromatic, layered, folded, boudin, schollen and agmatitic structures, occur in the upper half of the T3- $Z$ named the U-T3-Z (Fig. 2). The boundary between the L-T3-Z and the $\mathrm{U}-\mathrm{T} 3-\mathrm{Z}$ is gradational.

\section{Petrography}

Mesosome in both type- 1 and type- 2 is composed of the granulite facies metagabbro (banded metagabbro). On the other hand, the mesosome in type- 3 is composed of the amphibolite facies metagabbro (gneissose metagabbro). Microtextures of the mesosomes are characterized by a distinct lattice preferred orientation of clinopyroxene and hornblende (Fig. 4a, b). Leucosomes in both type- 1 and type -2 is composed of quartz bearing hornblende gabbro or quartz diorite, and rarely of tonalite. Compositional variation of leucosome in type-3 distinguishes the L-T3$\mathrm{Z}$ from $\mathrm{U}-\mathrm{T} 3-\mathrm{Z}$ (Fig. 2). Leucosome in the $\mathrm{L}-\mathrm{T} 3-\mathrm{Z}$ is composed exclusively of quartz diorite. On the other hand, the composition of leucosome in the U-T3-Z ranges from quartz bearing hornblende gabbro, quartz diorite and quartz monzodiorite through granodiorite to tonalite, trondhjemite and granite. Zircon and biotite particularly become more abundant in quartz monzodiorite, granodiorite and granite. Microtextures of leucosomes in all of the migmatites are characterized by poikilitic texture, where euhedral plagioclase crystals containing apatite inclusions are surrounded by coarse-grained subhedral hornblende (Fig. $4 \mathrm{~b}, \mathrm{c}$ ). These textures strongly indicate that the leucosomes formed by magmatic crystallization. Melanosome occurs in the T1-Z, T2-Z and L-T3-Z, which is composed of massive hornblendite with large amount of coarse-grained subhedral hornblende and small amount of plagioclase (Fig. 4d).

\section{Field relations}

Figure 5 shows the cross section of an outcrop, representing the successional migmatite sequences from $\mathrm{T} 1-\mathrm{Z}$ through T2-Z to L-T3-Z (Fig. 2). The type-1 and the type -2 occur in a lower half part of this cross section, at altitudes less than $535 \mathrm{~m}$, which corresponds to the $\mathrm{L}^{-}$ T1-Z and T2-Z (Fig. 2). Stromatic and dilation structures predominantly occur in its lowermost part, at an altitude around $450 \mathrm{~m}$, while diktyonitic structure predominantly occurs near the boundary between $\mathrm{T} 1-\mathrm{Z}$ and $\mathrm{T} 2-\mathrm{Z}$, at an altitude around $460 \mathrm{~m}$. Some trondhjemitic dykes occur in these zones, which often contain the angular blocks of type- 1 and type- 2 migmatites, forming an agmatitic structure. The composition of the leucosome at altitudes below $505 \mathrm{~m}$ is heterogeneous, ranging from quartz bearing hornblende gabbro through quartz diorite to tonalite, but most of them are quartz bearing hornblende gabbro. On the other hand, the composition of the leucosome gradually becomes homogenous, and dominantly quartz dioritic with increasing structural levels at altitudes above $505 \mathrm{~m}$.

The type- 3 occurs in an upper half part of this cross section, at an altitude higher than $535 \mathrm{~m}$, which corresponds to the L-T3-Z (Fig. 2). Most of the type-3 migmatite in this zone have schollen structure, where the volume percentage of leucosome is usually more than $70 \%$ (Fig. $3 \mathrm{~g}$ ). However, mesosome locally becomes abun- 

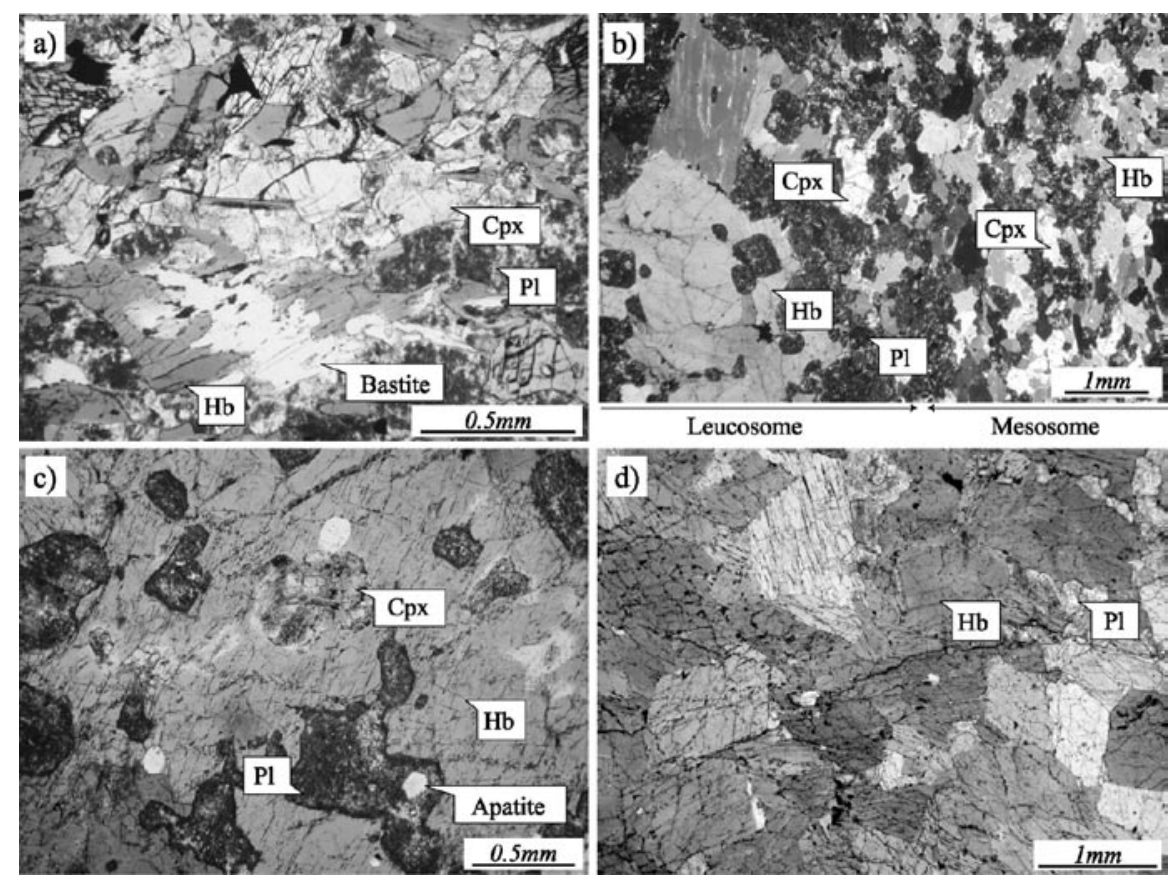

Figure 4. Photomicrographs showing textures in the rocks from the Asago body: (a) microtextures in granulite facies metagabbro, all of the orthopyroxene has been changed into bastite, (b) the boundary between leucosome and mesosome in type-2, (c) poikiliti texture in leucosomes in type-1, euhedral plagioclase crystals containing apatite inclusions are surrounded by coarse - grained subhedral hornblende, and (d) hornblendite in melanosome. (a) and (e) open crossed polarizer, (b) and (c) crossed polarizer. Most of the plagioclase in photomicrographs is saussuritized. Abbreviations: $\mathrm{Pl}$, plagioclase; Cpx, clinopyroxene; $\mathrm{Hb}$, hornblende. dant, where the volume percentage of leucosome decreases to less than $30 \%$. Layered structure occurs at the top of this zone.

\section{Mineral chemistry}

The chemical composition of amphibole, clinopyroxene and plagioclase from the M-Unit in the Asago body was analyzed using a JEOL electron-probe microanalyser (JCMA-733II) at the Natural Science Center for Basic Research and Development (N-BARD), Hiroshima University. The operating conditions were $12 \mathrm{nA}$ beam current, $15 \mathrm{kV}$ accelerating voltage and $5 \mu \mathrm{m}$ beam diameter.

\section{Plagioclase}

Plagioclase in the rocks from the M-Unit is moderately saussuritized or albitized, and any normal or oscillatory zoning cannot to be found. The plagioclase in the mafic metamorphic rocks and the later intrusion is albite to labradorite $(\mathrm{An}<52 \%)$ and albite to andesine $(\mathrm{An}<45 \%)$, respectively (Table 1).

\section{Amphibole}

Metamorphic amphiboles occur in the mafic metamorphic rocks, whereas magmatic amphibole occurs in the later intrusions. The metamorphic amphiboles are characterized by the distinct shape and lattice preferred orientation and elongated shape $0.5-1.0 \mathrm{~mm}$ in length. On the other hand, the magmatic amphiboles are characterized by sub- hedral and euhedral crystals with a grain size of 1.0-5.0 $\mathrm{mm}$. The structural formulae of amphiboles are calculated based on $\mathrm{O}=23$ per unit cell, and the $\mathrm{Fe}^{2+} / \mathrm{Fe}^{3+}$ ratio was estimated on the basis of total cations excluding $\mathrm{Ca}$, $\mathrm{Na}$ and K (Leake et al., 1997). Representative chemical compositions of the analyzed amphiboles; the portion of the highest $\mathrm{Al}$ and $\mathrm{Ti}$ content within the grains, are listed in Table 1. After the nomenclature by Leake et al. (1997), all of the analyzed amphiboles are classified as calcic amphibole, where $(\mathrm{Ca}+\mathrm{Na})$ and $\mathrm{Na}$ in $\mathrm{M} 4-$ site are greater than 1.0 and less than $0.5 \mathrm{pfu}$ (per formula unit), respectively. Amphiboles from both the mafic metamorphic rocks and the later intrusions show a wide range of composition mostly from magnesiohornblende through tschermakite to magnesiohastingsite (Fig. 6). In particular, amphiboles from granulite facies metagabbro are mostly tschermakite, whereas amphiboles from the well-foliated amphibolite are mostly magnesiohornblende.

\section{Clinopyroxene}

Clinopyroxene from the metagabbro of plagioclase + clinopyroxene assemblage (light-layer from the banded metagabbro) is the smallest (ca. $0.3 \mathrm{~mm}$ ), in which clinopyroxene shows distinct lattice preferred orientation. On the other hand, clinopyroxene from the metagabbro of plagioclase + clinopyroxene + orthopyroxene + hornblende assemblage (granulite facies metagabbro) and that from the metagabbro of plagioclase + clinopyroxene + hornblende mineral assemblage (amphibolite facies metagabbro) are relatively large $(c a .0 .7 \mathrm{~mm})$, in which 


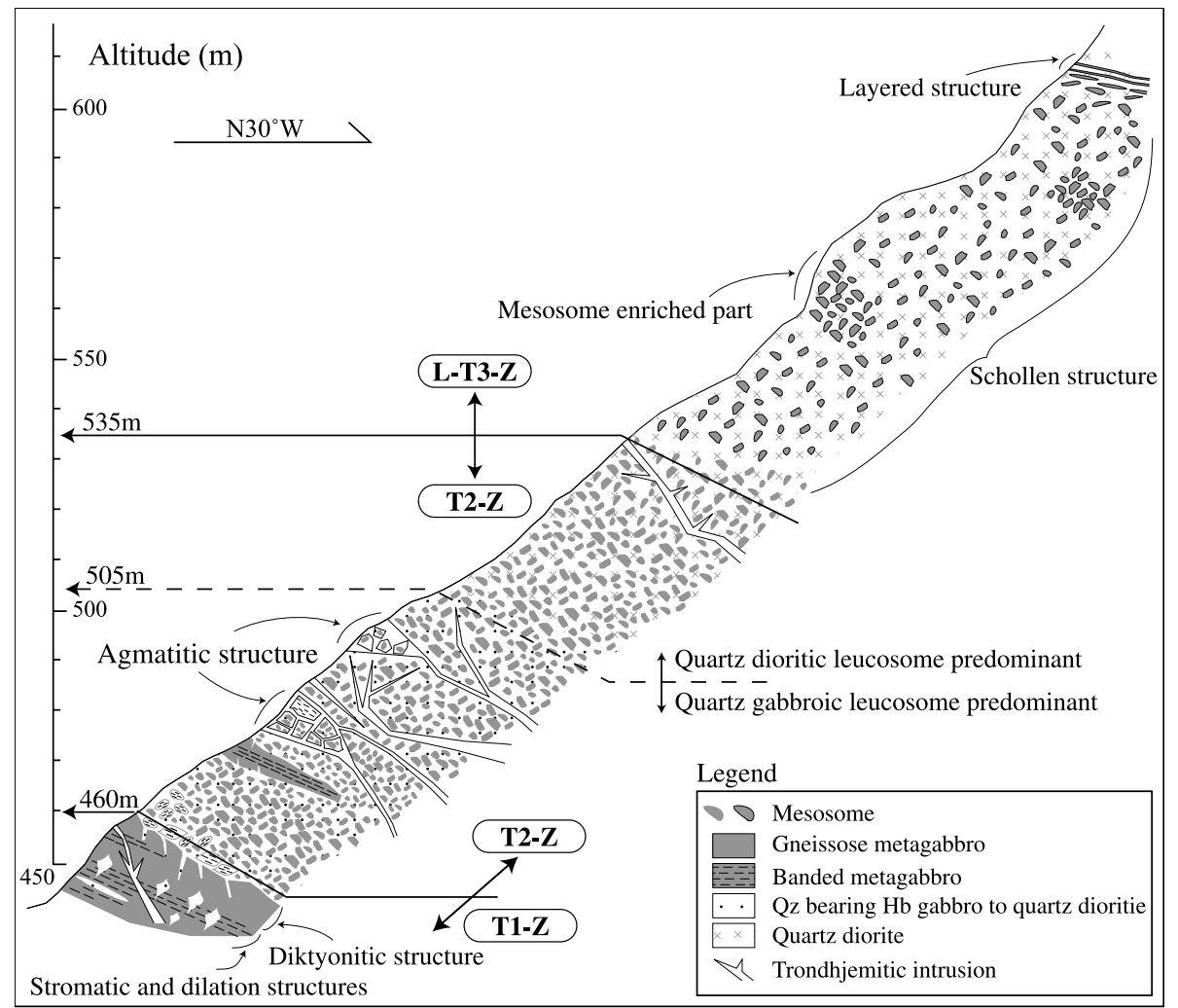

Figure 5. Cross-section along an outcrop representing the migmatite zones from the type- 1 zone (T1-Z) through the type-2 zone (T2-Z) to the lower half of type3 zone (L-T3-Z). Locality is shown in Figure 1a. the clinopyroxene does not show distinct lattice preferred orientation. Representative chemical compositions of the analyzed clinopyroxenes are listed in Table 2. The Mg\# $(100 \mathrm{Mg} /[\mathrm{Mg}+\mathrm{Fe}])$ values of clinopyroxene from the granulite facies metagabbro and the amphibolite facies metagabbro range from 63-66 and from 68-73, respectively. On the other hand, clinopyroxene from the lightcolored layer in the banded metagabbro of plagioclase + clinopyroxene mineral assemblage range from 49-55. These results indicate that the $\mathrm{Mg} \#$ value increases with a decreasing grade of metamorphism. Furthermore, the chemistry of clinopyroxene is related their mineral assemblage of the host rocks.

\section{Bulk rock chemistry}

Major and trace element compositions were determined for representative whole-rock specimens of 30 samples of mafic metamorphic rocks, 60 samples of later intrusions including 29 samples of leucosome, and 2 samples of melanosome, by a Rigaku ZSX-101e X-ray fluorescence spectrometer (XRF), equipped with $\mathrm{Rh} / \mathrm{W}$ dual-anode $\mathrm{X}^{-}$ ray tube, at Hiroshima University. Accelerating voltage and tube current were $50 \mathrm{kV}$ and $50 \mathrm{~mA}$, respectively. Whole rock analyses are summarized in Tables 3 and 4 .

In order to interpret petrogenesis from the chemical characteristics of the rocks, the mobility of relevant ele- ments during possible metasomatism must be considered. The presence of irregularly distributed biotite in the mafic metamorphic rocks suggests $\mathrm{K}$-metasomatism by alkali fluid injection, by which the whole-rock chemistry of original mafic metamorphic rocks could have been altered. Furthermore, the presence of saussuritization and sericitisation of plagioclase, serpentinization and chloritization of orthopyroxene, and chloritization of biotite indicates secondary alternation. On the diagram of $\mathrm{K}_{2} \mathrm{O}$ versus $\mathrm{SiO}_{2}$ (Fig. 7), $\mathrm{K}_{2} \mathrm{O}$ contents of the rocks in this study area are highly scattered between 0.1 and $3.9 \mathrm{wt} \%$. As described below, the mafic metamorphic rocks belong to a MORB-like gabbro series, in which $\mathrm{K}_{2} \mathrm{O}$ content is usually less than $0.5 \mathrm{wt} \%$ (cf. Plume MORB; Wilson, 1989). Therefore, a wide range and enrichment of $\mathrm{K}_{2} \mathrm{O}$ content in the mafic metamorphic rocks $(0.18-2.1 \mathrm{wt} \%)$ indicate the rocks suffered an effect of $\mathrm{K}$-metasomatism.

Harker variation diagrams of selective major elements versus $\mathrm{SiO}_{2}$ are shown in Figure 7. $\mathrm{TiO}_{2}, \mathrm{Al}_{2} \mathrm{O}_{3}$, $\mathrm{FeO}^{*}, \mathrm{MgO} \mathrm{CaO}$ and $\mathrm{Na}_{2} \mathrm{O}$ contents show relatively strong negative or positive correlation with increasing $\mathrm{SiO}_{2}$ content, whereas $\mathrm{K}_{2} \mathrm{O}$ content does not show definite uniform correlation with increasing $\mathrm{SiO}_{2}$ content, indicating significant $\mathrm{K}$-metasomatism as discussed above. Melanosomes have compositional range of $\mathrm{SiO}_{2}$ between 42 and $43 \mathrm{wt} \%$, and relatively higher $\mathrm{FeO}^{*}$ and $\mathrm{MgO}$ content than the other rock suites, which is classified into ultra- 
Table 1. Representative amphibole compositions for rocks from the Asago body

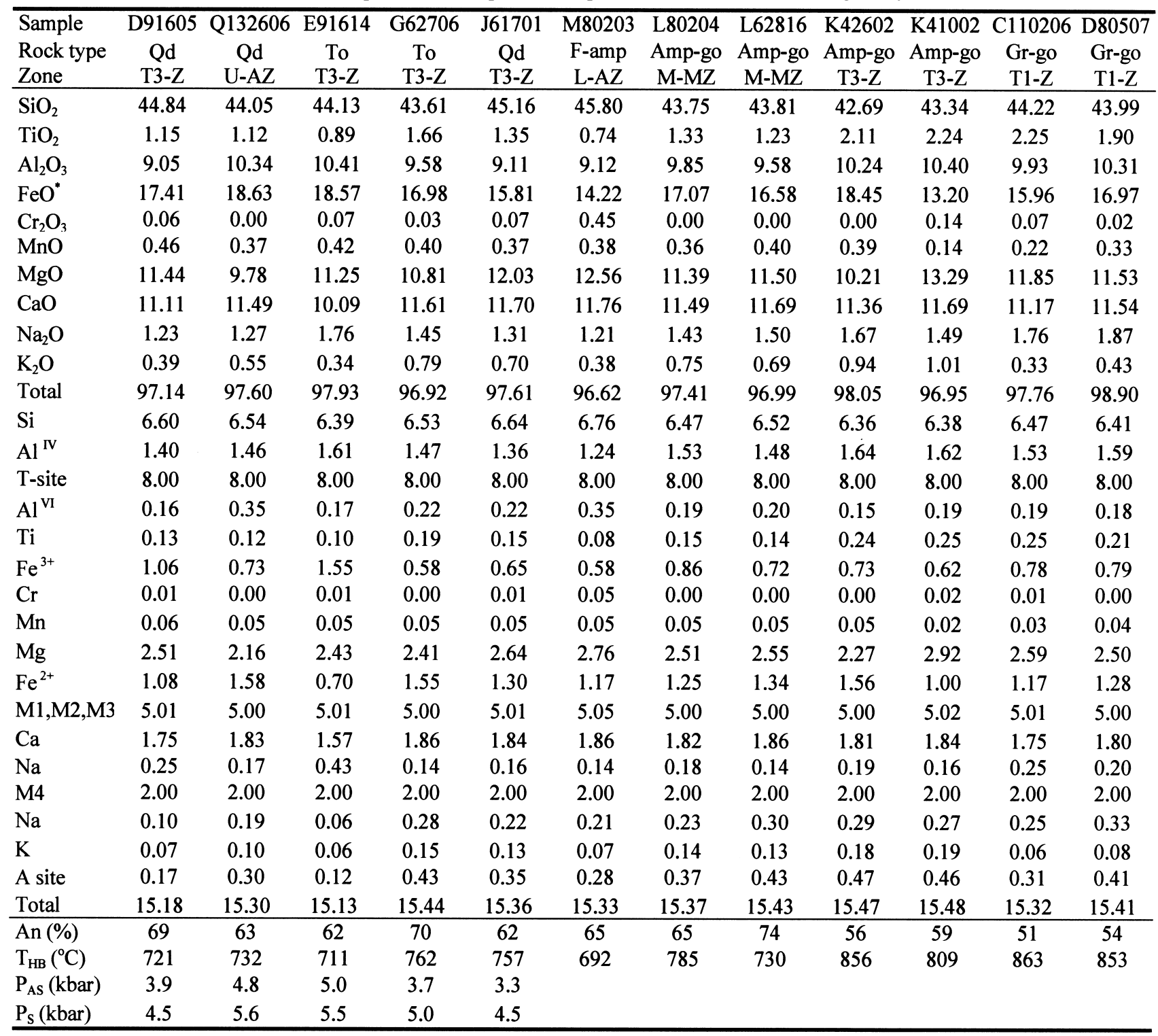

Abbreviations: $\mathrm{P}_{\mathrm{S}}$, Schmidt (1992); $\mathrm{T}_{\mathrm{HB}}$, Holland and Blundy (1994); $\mathrm{P}_{\mathrm{AS}}$, Anderson and Smith (1995); Gr-go, granulite facies metagabbro; Amp-go, amphibolite facies metagabbro; F-amp; well-foliated amphibolite; Qd, quartz diorite; To, tonalite; T1-Z, type-1 zone; T3-Z, type-3 zone; $\mathrm{U}-\mathrm{AZ}$, upper amphibolite zone; $\mathrm{M}-\mathrm{MZ}$, middle metagabbro zone.

mafic rocks. The mafic metamorphic rocks have a restricted compositional range of $\mathrm{SiO}_{2}$ between 46 and 50 wt $\%$. Compositional ranges of $\mathrm{TiO}_{2}, \mathrm{FeO}^{*}$ and $\mathrm{MgO}$ in the well-foliated amphibolite are smaller and completely included in those in the metagabbro. Compositional ranges of $\mathrm{SiO}_{2}$ content in later intrusions are quite large. Leucosome (i.e. later intrusions in the Migmatite zone) has a compositional range of $\mathrm{SiO}_{2}$ between 48 and 71 $\mathrm{wt} \%$, while plutons and dykes (i.e. later intrusions in the middle to upper part of the $\mathrm{M}$-Unit) have a compositional range of $\mathrm{SiO}_{2}$ between 52 and $76 \mathrm{wt} \%$. The leucosomes show a unimodal distribution of $\mathrm{SiO}_{2}$ content with the above range with the mean content of 58 wt $\%$. In contrast, the plutons and dykes show a bimodal distribution of $\mathrm{SiO}_{2}$ content; one at $52-67 \mathrm{wt} \%$ with a mean content of $57 \mathrm{wt} \%$, the other at $72-76 \mathrm{wt} \%$ with a mean content of $74 \mathrm{wt} \%$. In this study, the former is named "plutons and dykes of medium-silica content", the latter is named "plutons and dykes of high-silica content". The plutons and dykes of high-silica content have uniform contents of $\mathrm{TiO}_{2}, \mathrm{Al}_{2} \mathrm{O}_{3}, \mathrm{FeO}^{*}, \mathrm{MgO}$ and $\mathrm{CaO}$, and they have lower $\mathrm{TiO}_{2}, \mathrm{FeO}^{*}, \mathrm{MgO}$ and $\mathrm{CaO}$ content than those of the other rock suites. 


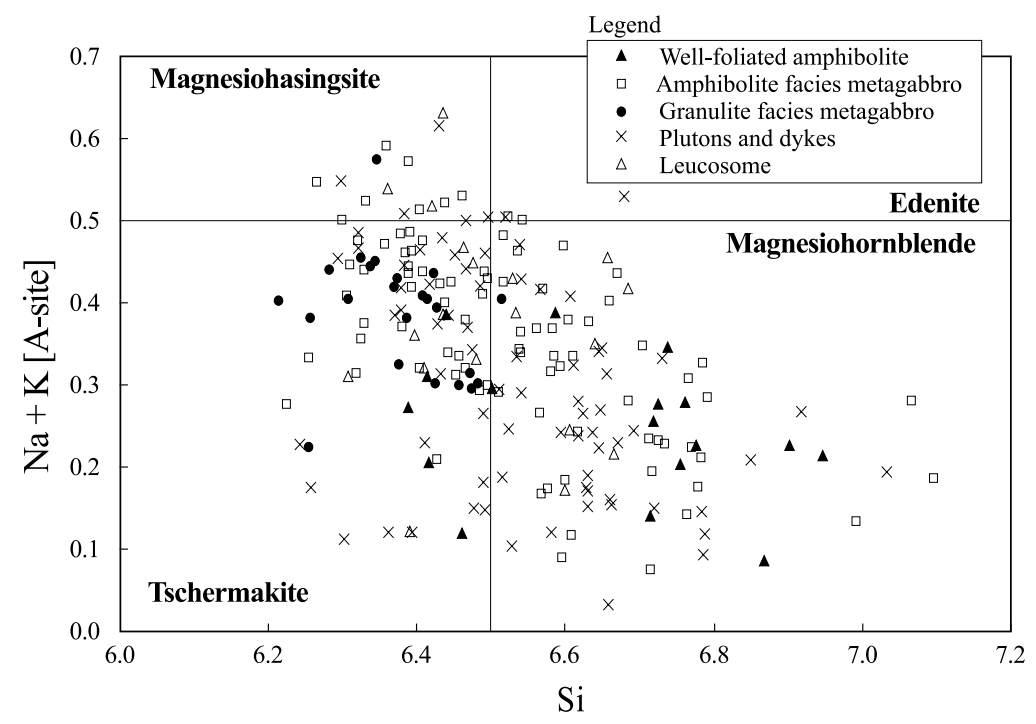

Figure 6. Classification of calcic amphiboles $(\mathrm{Na}+$ $\mathrm{K}$ [A-site] vs. Si diagram) for those from the Asago body. Nomenclature after Leake et al. (1997).
Table 2. Representative clinopyroxene compositions for mafic metamorphic rocks from the Asago body

\begin{tabular}{|c|c|c|c|c|c|}
\hline \multirow{3}{*}{$\begin{array}{l}\text { Rock type } \\
\text { Sample }\end{array}$} & \multirow{2}{*}{$\begin{array}{l}\text { Band-go } \\
\mathrm{Pl}+\mathrm{Cpx}\end{array}$} & \multicolumn{2}{|c|}{ Gr-go } & \multicolumn{2}{|c|}{ Amp-go } \\
\hline & & $\begin{array}{c}\mathrm{Pl}+\mathrm{Cpx}+ \\
\mathrm{Opx}+\mathrm{Hb}\end{array}$ & $\begin{array}{l}\mathrm{Pl}+\mathrm{Cpx}+ \\
\mathrm{Opx}+\mathrm{Hb}\end{array}$ & $\begin{array}{l}\mathrm{Pl}+\mathrm{Cpx} \\
+\mathrm{Hb}\end{array}$ & $\begin{array}{c}\mathrm{Pl}+\mathrm{Cpx} \\
+\mathrm{Hb}\end{array}$ \\
\hline & $\mathrm{H} 5-0000$ & I12-2201 & D9-2601 & D9-2601 & H4-2801 \\
\hline $\mathrm{SiO}_{2}$ & 50.65 & 51.40 & 51.71 & 51.55 & 51.34 \\
\hline $\mathrm{TiO}_{2}$ & 0.16 & 0.21 & 0.15 & 0.15 & 0.18 \\
\hline $\mathrm{Al}_{2} \mathrm{O}_{3}$ & 1.22 & 1.45 & 1.14 & 1.32 & 1.38 \\
\hline $\mathrm{FeO}^{*}$ & 14.72 & 13.01 & 11.29 & 8.73 & 10.93 \\
\hline $\mathrm{MnO}$ & 0.38 & 0.41 & 0.40 & 0.64 & 0.71 \\
\hline $\mathrm{MgO}$ & 9.93 & 12.44 & 12.40 & 13.33 & 13.04 \\
\hline $\mathrm{CaO}$ & 22.26 & 20.62 & 22.07 & 22.14 & 22.24 \\
\hline $\mathrm{Na}_{2} \mathrm{O}$ & 0.31 & 0.31 & 0.24 & 0.39 & 0.37 \\
\hline $\mathrm{K}_{2} \mathrm{O}$ & 0.00 & 0.00 & 0.01 & 0.01 & 0.02 \\
\hline Total & 99.62 & 99.85 & 99.40 & 98.27 & 100.22 \\
\hline $\mathrm{O}=$ & 24 & 24 & 24 & 24 & 24 \\
\hline $\mathrm{Si}$ & 7.83 & 7.82 & 7.86 & 7.85 & 7.76 \\
\hline $\mathrm{Ti}$ & 0.02 & 0.02 & 0.02 & 0.02 & 0.02 \\
\hline $\mathrm{Al}$ & 0.22 & 0.26 & 0.20 & 0.24 & 0.25 \\
\hline $\mathrm{Fe}$ & 1.90 & 1.65 & 1.44 & 1.11 & 1.38 \\
\hline $\mathrm{Mn}$ & 0.05 & 0.05 & 0.05 & 0.08 & 0.09 \\
\hline $\mathrm{Mg}$ & 2.29 & 2.82 & 2.81 & 3.03 & 2.94 \\
\hline $\mathrm{Ca}$ & 3.69 & 3.36 & 3.60 & 3.61 & 3.60 \\
\hline $\mathrm{Na}$ & 0.09 & 0.09 & 0.07 & 0.12 & 0.11 \\
\hline $\mathrm{K}$ & 0.00 & 0.00 & 0.00 & 0.00 & 0.00 \\
\hline $\mathrm{Mg} \#$ & 54.59 & 63.03 & 66.19 & 73.13 & 68.02 \\
\hline
\end{tabular}

Abbreviations: $\mathrm{Pl}$, plagioclase; $\mathrm{Cpx}$, clinopyroxene; Opx, orthopyroxene; $\mathrm{Hb}$, hornblende; Band- ${ }^{-}$o, banded metagabbro; others are the same in Table 1.

\section{Discussion}

\section{Origin of the M-Unit}

On discrimination diagrams between tholeiitic and calcalkalic series $\left(\mathrm{SiO}_{2}-\mathrm{FeO}^{*} / \mathrm{MgO}, \mathrm{FeO}^{*}-\mathrm{FeO}^{*} / \mathrm{MgO}\right.$ and $\mathrm{TiO}_{2}-\mathrm{FeO}^{*} / \mathrm{MgO}$ diagrams; Miyashiro, 1975), the mafic metamorphic rocks including mesosome are plotted in the tholeiitic field. They show a similar geochemical trend to those of the mid-ocean-ridge basalt (MORB) (Fig. 8). It is concluded therefore that they originated from oceanic crust. On the same diagrams, almost all of the later intrusions; plutons, dykes and leucosome suites, clearly show an calc-alkaline affinity (Fig. 8). All of granitoid in this study area are plotted on a diagram to estimate the tectonic setting for granitoid (Nb-Y diagram; Pearce et al., 1984), in the volcanic arc and syn-collisional granite field (Fig. 9). Furthermore, strong deformation coeval with the magmatism, noted above, suggests that this complex was situated in a magmatic arc environment near a convergent margin before its emplacement as ophiolite. The abundance of felsic rocks, especially of $\mathrm{K}$-feldspar bearing granitoid, and the presence of mafic metamorphic rocks composed solely of ophiolitic mafic rocks with no terrigenous deposit indicate that the M-Unit does not represent a continental arc crust, but an immature intra-oceanic island arc crust.

\section{Magma segregation processes}

Figure 10 illustrates schematically the field relationships inferred from the cross section shown in Figure 5. The relation of the U-T3-Z, U-AZ and M-MZ (Fig. 2) to the geology of the areas also added in this figure. The most 
Table 3. Representative bulk rock compositions for mafic metamorphic rocks from the Asago body

\begin{tabular}{|c|c|c|c|c|c|c|c|c|c|c|c|c|}
\hline Sample & 306 & 81 & 420 & 421 & 14 & 422 & 309 & 307 & 101 & 108 & 113 & 114 \\
\hline Rock type & Amp-go & Amp-go & Amp-go & Amp-go & Hbd & Hbd & Gr-go & Gr-go & Amp-go & Amp-go & F-amp & F-amp \\
\hline Zone & $\mathrm{T} 1-\mathrm{Z}$ & $\mathrm{T} 2-\mathrm{Z}$ & T3-Z & $\mathrm{T} 2-\mathrm{Z}$ & $\mathrm{T} 1-\mathrm{Z}$ & $\mathrm{T} 1-\mathrm{Z}$ & $\mathrm{M}-\mathrm{MZ}$ & M-MZ & M-MZ & M-MZ & $\mathrm{U}-\mathrm{AZ}$ & $\mathrm{U}-\mathrm{AZ}$ \\
\hline \multicolumn{13}{|c|}{ Major element (wt\%) } \\
\hline $\mathrm{SiO}_{2}$ & 48.86 & 48.47 & 50.21 & 47.22 & 43.19 & 41.66 & 46.70 & 46.12 & 48.96 & 48.55 & 49.18 & 47.60 \\
\hline $\mathrm{TiO}_{2}$ & 1.65 & 1.12 & 1.18 & 1.75 & 1.38 & 0.52 & 1.25 & 1.43 & 1.63 & 1.76 & 1.69 & 1.39 \\
\hline $\mathrm{Al}_{2} \mathrm{O}_{3}$ & 15.06 & 15.57 & 17.63 & 14.13 & 10.26 & 12.50 & 15.85 & 16.71 & 15.09 & 15.26 & 15.67 & 15.72 \\
\hline $\mathrm{FeO}^{*}$ & 11.18 & 10.57 & 8.78 & 13.07 & 16.72 & 14.58 & 10.53 & 11.21 & 10.49 & 11.03 & 9.70 & 11.21 \\
\hline $\mathrm{MnO}$ & 0.19 & 0.18 & 0.19 & 0.26 & 0.28 & 0.25 & 0.19 & 0.17 & 0.20 & 0.21 & 0.20 & 0.24 \\
\hline $\mathrm{MgO}$ & 7.80 & 5.54 & 5.92 & 8.06 & 12.39 & 17.38 & 8.72 & 6.51 & 6.89 & 6.94 & 6.54 & 8.15 \\
\hline $\mathrm{CaO}$ & 7.71 & 13.94 & 7.09 & 7.84 & 9.92 & 7.63 & 10.94 & 11.29 & 8.35 & 8.08 & 8.62 & 7.38 \\
\hline $\mathrm{Na}_{2} \mathrm{O}$ & 3.80 & 2.49 & 3.84 & 3.36 & 1.30 & 0.78 & 2.93 & 2.99 & 3.62 & 3.68 & 3.43 & 3.43 \\
\hline $\mathrm{K}_{2} \mathrm{O}$ & 0.80 & 0.18 & 2.07 & 0.92 & 0.34 & 0.22 & 0.30 & 0.45 & 1.13 & 1.20 & 1.33 & 0.96 \\
\hline $\mathrm{P}_{2} \mathrm{O}_{5}$ & 0.16 & 0.10 & 0.32 & 0.18 & 0.03 & 0.04 & 0.13 & 0.16 & 0.23 & 0.24 & 0.22 & 0.13 \\
\hline Total & 97.20 & 98.16 & 97.22 & 96.80 & 95.80 & 95.55 & 97.53 & 97.04 & 96.60 & 96.94 & 96.57 & 96.22 \\
\hline \multicolumn{13}{|c|}{ Trace element (ppm) } \\
\hline Sc & 47.0 & 37.6 & 33.3 & 44.4 & 67.3 & 34.8 & 40.4 & 43.7 & 39.5 & 42.1 & 42.2 & 41.2 \\
\hline V & 389 & 339 & 245 & 310 & 536 & 221 & 302 & 328 & 296 & 313 & 318 & 292 \\
\hline $\mathrm{Cr}$ & 134 & 219 & 99.1 & 242 & 810 & 1899 & 316 & 191 & 176 & 186 & 196 & 222 \\
\hline Co & 48.0 & 36.1 & 32.8 & 45.1 & 63.8 & 81.0 & 61.9 & 53.3 & 69.6 & 49.3 & 67.4 & 56.2 \\
\hline $\mathrm{Ni}$ & 62.8 & 67.8 & 41.9 & 87.7 & 157 & 591 & 113 & 64.5 & 54.4 & 49.5 & 52.4 & 79.9 \\
\hline $\mathrm{Cu}$ & 86.3 & 5.2 & 55.0 & $<2.36$ & 58.1 & $<2.36$ & 64.3 & 102 & 4.5 & 62.2 & 56.6 & 19.8 \\
\hline $\mathrm{Zn}$ & 98.3 & 79.0 & 88.9 & 128 & 161 & 111 & 101 & 93.4 & 91.7 & 90.7 & 94.7 & 107 \\
\hline $\mathrm{Ga}$ & 15.6 & 21.2 & 18.4 & 16.5 & 20.2 & 16.8 & 16.4 & 18.6 & 18.2 & 18.6 & 17.8 & 21.4 \\
\hline $\mathrm{Rb}$ & 14.9 & 2.5 & 57.3 & 17.5 & 2.4 & 2.4 & 2.1 & 5.1 & 24.8 & 27.7 & 28.3 & 24.9 \\
\hline $\mathrm{Sr}$ & 271 & 703 & 567 & 154 & 40.7 & 21.3 & 241 & 392 & 334 & 390 & 356 & 294 \\
\hline$Y$ & 31.3 & 18.1 & 20.0 & 31.5 & 59.2 & 21.8 & 22.9 & 27.7 & 28.6 & 35.0 & 31.5 & 23.0 \\
\hline $\mathrm{Zr}$ & 55.1 & 34.8 & 108 & 83.2 & 62.1 & 25.2 & 60.1 & 72.2 & 111 & 148 & 133 & 84.9 \\
\hline $\mathrm{Nb}$ & 4.0 & 1.7 & 4.8 & 2.3 & 2.2 & 1.3 & 1.7 & 1.6 & 3.8 & 3.0 & 3.5 & 1.2 \\
\hline $\mathrm{Ba}$ & 208 & 69.7 & 898 & 514 & 56.0 & 34.9 & 73.9 & 126 & 224 & 415 & 573 & 439 \\
\hline $\mathrm{La}$ & 7.3 & 5.2 & 16.2 & 6.1 & 11.2 & 4.4 & 1.9 & 4.4 & 7.8 & 9.2 & 10.4 & 3.9 \\
\hline $\mathrm{Ce}$ & 21.7 & 10.0 & 40.9 & 17.0 & 35.7 & 20.0 & 11.6 & 16.2 & 21.3 & 24.5 & 24.0 & 12.8 \\
\hline $\operatorname{Pr}$ & 2.1 & 2.0 & 5.4 & 1.8 & 4.6 & 2.2 & 1.1 & 2.0 & 1.7 & $<1.5$ & $<1.5$ & $<1.5$ \\
\hline $\mathrm{Nd}$ & 13.2 & 8.5 & 22.2 & 14.8 & 22.3 & 10.9 & 8.8 & 11.0 & 16.3 & 18.0 & 18.0 & 11.0 \\
\hline $\mathrm{Sm}$ & 4.8 & 1.4 & 4.4 & 5.0 & 7.3 & 4.7 & 4.6 & 4.6 & 2.6 & 2.9 & 2.7 & 2.4 \\
\hline $\mathrm{Gd}$ & 5.3 & 1.3 & 5.2 & 6.6 & 8.9 & 4.1 & 4.2 & 4.5 & 2.3 & 2.6 & 2.3 & 2.2 \\
\hline Dy & 5.7 & 1.1 & 4.6 & 5.4 & 8.1 & 3.6 & 3.9 & 5.0 & 3.1 & 2.8 & 2.4 & 2.3 \\
\hline $\mathrm{Er}$ & 1.8 & $<0.37$ & $<0.37$ & 2.0 & 3.8 & $<0.37$ & 1.4 & 1.4 & 1.3 & 1.4 & $<0.37$ & 1.1 \\
\hline $\mathrm{Yb}$ & 3.9 & 2.6 & 1.4 & 3.0 & 8.3 & 2.7 & 3.5 & 3.3 & 4.2 & 3.3 & 4.3 & 3.2 \\
\hline $\mathrm{Hf}$ & 1.0 & 1.3 & 2.2 & 0.9 & 1.2 & $<0.63$ & 1.0 & 1.0 & 2.4 & 3.7 & 2.9 & 1.8 \\
\hline $\mathrm{Pb}$ & 3.6 & 2.7 & 7.4 & 1.3 & 1.2 & 2.2 & 1.4 & 1.0 & 2.2 & 0.8 & 5.8 & 0.8 \\
\hline Th & 4.7 & $<0.65$ & 2.6 & 3.0 & 4.3 & 3.2 & 1.0 & 0.6 & 3.2 & 3.4 & 0.9 & 1.4 \\
\hline
\end{tabular}

"Total Fe as FeO. Abbreviations: Hbd, hornblendite; T2-Z, type-2 zone; others are the same in Table 1.

important observation from the sketch is that the volume percentage of leucosome in the migmatites increases upward, and the composition of the leucosome also changes upward from mafic through intermediate to felsic. The granitoid which contains $\mathrm{K}$-feldspar such as quartz monzodiorite, granodiorite and granite, do not occur in the basal part of the migmatite zone, but only in the U-T3-Z,
$\mathrm{U}-\mathrm{AZ}$ and $\mathrm{M}-\mathrm{MZ}$. If these occurrences directly represent the granitoid magma generation processes in the M-Unit, the morphological change of the migmatite shape from type- 1 through type- 2 to type- 3 , can be explained by the degree of melt segregation. It can be concluded that the melt segregation starts at the $\mathrm{T} 1-\mathrm{Z}$ and its degree increases upward through the $\mathrm{T} 2-\mathrm{Z}$ and $\mathrm{T} 3-\mathrm{Z}$, finally leading to 
Table 4. Representative bulk rock compositions for later intrusions from the Asago body

\begin{tabular}{|c|c|c|c|c|c|c|c|c|c|c|c|c|}
\hline Sample & 166 & 58 & 402 & 408 & 406 & 404 & 302 & 155 & 417 & 148 & 168 & 303 \\
\hline Rock type & To & To & Qd & $\mathrm{Gr}$ & Mzdq & $\mathrm{Gd}$ & Qd & To & $\mathrm{Gd}$ & Qd & $\mathrm{Gd}$ & H-go \\
\hline Species & T1-Leu & T2-Leu & T3-Leu & T3-Leu & T3-Leu & T3-Leu & PD & PD & PD & PD & PD & PD \\
\hline \multicolumn{13}{|c|}{ Major element (wt\%) } \\
\hline $\mathrm{SiO}_{2}$ & 68.55 & 62.44 & 55.33 & 64.17 & 60.29 & 59.75 & 56.28 & 73.39 & 76.14 & 58.82 & 74.99 & 52.85 \\
\hline $\mathrm{TiO}_{2}$ & 0.20 & 0.52 & 0.98 & 0.84 & 1.04 & 0.95 & 1.15 & 0.30 & 0.15 & 0.80 & 0.11 & 0.67 \\
\hline $\mathrm{Al}_{2} \mathrm{O}_{3}$ & 13.99 & 16.54 & 15.43 & 15.97 & 18.04 & 17.14 & 15.97 & 12.84 & 13.46 & 16.99 & 13.14 & 16.53 \\
\hline $\mathrm{FeO}^{*}$ & 2.55 & 3.96 & 9.09 & 4.38 & 4.22 & 5.35 & 10.11 & 2.25 & 1.26 & 5.43 & 1.01 & 8.38 \\
\hline $\mathrm{MnO}$ & 0.06 & 0.09 & 0.18 & 0.12 & 0.17 & 0.09 & 0.20 & 0.07 & 0.04 & 0.10 & 0.01 & 0.17 \\
\hline $\mathrm{MgO}$ & 1.81 & 2.45 & 4.56 & 1.85 & 1.62 & 3.12 & 4.22 & 0.72 & 0.38 & 3.61 & 0.28 & 5.91 \\
\hline $\mathrm{CaO}$ & 4.89 & 6.85 & 6.71 & 1.84 & 2.89 & 4.64 & 3.64 & 1.12 & 0.62 & 5.65 & 0.75 & 6.63 \\
\hline $\mathrm{Na}_{2} \mathrm{O}$ & 4.87 & 4.37 & 4.04 & 4.12 & 5.05 & 3.69 & 4.86 & 5.36 & 4.63 & 4.62 & 4.84 & 4.79 \\
\hline $\mathrm{K}_{2} \mathrm{O}$ & 0.44 & 0.41 & 0.78 & 3.48 & 3.86 & 2.35 & 0.52 & 0.43 & 3.08 & 1.01 & 3.19 & 0.35 \\
\hline $\mathrm{P}_{2} \mathrm{O}_{5}$ & 0.02 & 0.06 & 0.10 & 0.20 & 0.20 & 0.26 & 0.17 & 0.04 & 0.03 & 0.19 & 0.01 & 0.09 \\
\hline total & 97.39 & 97.69 & 97.20 & 98.04 & 98.04 & 97.31 & 97.11 & 96.52 & 99.79 & 97.21 & 98.34 & 97.30 \\
\hline \multicolumn{13}{|c|}{ Trace element (ppm) } \\
\hline $\mathrm{Sc}$ & 11.6 & 14.6 & 34.7 & 6.0 & 6.9 & 15.1 & 36.1 & 14.8 & 1.6 & 16.1 & $<1.23$ & 32.2 \\
\hline V & 74.8 & 99.6 & 253 & 91.4 & 56.0 & 128 & 267 & 14.1 & 13.8 & 133 & 8.7 & 205 \\
\hline $\mathrm{Cr}$ & 103 & 55.3 & 34 & 21.2 & 22.7 & 56.8 & 36.9 & 6.0 & 17.9 & 46.7 & 6.0 & 89.5 \\
\hline Co & 9.8 & 107 & 71.4 & 47.1 & 41.3 & 55.7 & 56.3 & 67.1 & 126 & 71.0 & 136 & 68.8 \\
\hline $\mathrm{Ni}$ & 21.5 & 20.9 & 16.0 & 7.9 & 10.1 & 24.9 & 11.2 & 4.1 & 2.7 & 26.6 & 2.0 & 28.7 \\
\hline $\mathrm{Cu}$ & 8.8 & 4.0 & 26.8 & 5.4 & 12.4 & 16.9 & $<2.36$ & 2.5 & 2.6 & 12.1 & 3.6 & 6.1 \\
\hline $\mathrm{Zn}$ & 32.2 & 43.5 & 81.4 & 79.7 & 77.4 & 67.4 & 90.3 & 36.0 & 23.2 & 64.0 & 12.1 & 69.4 \\
\hline $\mathrm{Ga}$ & 12.6 & 18.1 & 18.4 & 18.0 & 17.4 & 18.8 & 15.5 & 15.9 & 13.6 & 18.3 & 12.8 & 13.6 \\
\hline $\mathrm{Rb}$ & 6.2 & 3.6 & 8.6 & 116 & 44.5 & 61.9 & 10.4 & 9.8 & 90.1 & 18.9 & 37.6 & 8.5 \\
\hline $\mathrm{Sr}$ & 216 & 572 & 360 & 323 & 557 & 620 & 161 & 238 & 172 & 649 & 68.1 & 165 \\
\hline $\mathrm{Y}$ & 26.8 & 27.1 & 36.3 & 8.7 & 10.1 & 13.1 & 27.6 & 35.8 & 18.4 & 12.5 & 12.8 & 17.1 \\
\hline $\mathrm{Zr}$ & 51.2 & 149 & 83.1 & 615 & 463 & 473 & 133 & 145 & 113 & 189 & 98.5 & 67.9 \\
\hline $\mathrm{Nb}$ & 2.4 & 4.8 & 3.0 & 9.6 & 10.7 & 8.4 & 3.9 & 5.3 & 9.0 & 5.3 & 7.3 & 3.2 \\
\hline $\mathrm{Ba}$ & 128 & 139 & 199 & 1147 & 3218 & 1428 & 79.2 & 93.3 & 701 & 356 & 612 & 87.5 \\
\hline $\mathrm{La}$ & 2.9 & 7.0 & 6.9 & 17.9 & 23.1 & 23.2 & 5.7 & 6.3 & 16.8 & 15.0 & 24.6 & 3.2 \\
\hline $\mathrm{Ce}$ & 9.6 & 19.1 & 24.8 & 52.3 & 51.3 & 57.5 & 17.3 & 16.8 & 34.2 & 35.6 & 42.2 & 11.1 \\
\hline $\operatorname{Pr}$ & 2.1 & 1.6 & 1.7 & 4.6 & 3.8 & 4.9 & 2.4 & 2.2 & 4.2 & 3.9 & 5.4 & 2.0 \\
\hline $\mathrm{Nd}$ & 7.9 & 14.5 & 16.8 & 23.8 & 26.0 & 28.0 & 10.8 & 12.4 & 13.0 & 16.9 & 14.7 & 6.9 \\
\hline $\mathrm{Sm}$ & 3.5 & 2.3 & 4.5 & 2.8 & 2.9 & 2.9 & 4.7 & 5.7 & 4.0 & 3.5 & 2.9 & 4.2 \\
\hline $\mathrm{Gd}$ & 2.6 & 1.9 & 5.6 & 3.6 & 5.0 & 4.3 & 4.4 & 3.7 & 3.1 & 4.1 & 2.8 & 2.7 \\
\hline Dy & 3.0 & 2.5 & 5.3 & 2.5 & 3.1 & 1.8 & 5.7 & 6.5 & 3.5 & 3.4 & 3.0 & 2.7 \\
\hline Er & $<0.37$ & $<0.37$ & 1.4 & $<0.37$ & $<0.37$ & $<0.37$ & 1.5 & 1.6 & $<0.37$ & $<0.37$ & $<0.37$ & $<0.37$ \\
\hline $\mathrm{Yb}$ & 1.4 & 7.0 & 6.3 & 3.6 & 3.8 & 2.7 & 4.0 & 7.4 & 8.8 & 1.6 & 8.0 & 2.3 \\
\hline Hf & 2.2 & 4.2 & 1.6 & 10.0 & 7.1 & 7.6 & 2.9 & 4.1 & 3.2 & 3.9 & 2.8 & 1.4 \\
\hline $\mathrm{Pb}$ & 2.3 & 2.6 & 1.8 & 7.3 & 12.7 & 6.1 & 3.7 & 1.0 & 13.3 & 3.8 & 18.8 & 1.2 \\
\hline Th & 3.3 & 1.4 & 1.1 & 4.0 & 5.2 & 1.6 & 1.8 & 5.5 & 14.0 & 2.5 & 28.7 & 4.4 \\
\hline
\end{tabular}

"Total Fe as FeO. Abbreviations: Gr, granite; Mzdq, quartz monzodiorite; Gd, granodiorite; H-go, hornblende gabbro; T1-Leu, leucosome in type-1; T2-Leu, leucosome in type-2; T3-Leu, leucosome in type-3; PD, plutons and dykes; others are the same in Table 1.

the formation of granitoid plutons.

\section{Pressure and temperature conditions}

To estimate the approximate temperature $(\mathrm{T})$ and pressure (P) conditions of crystallization or recrystallization of am- phiboles, aluminum-in-hornblende ( $\mathrm{AH})$ barometry (Schmidt, 1992; Anderson and Smith, 1995) and amphibole-plagioclase (hb-pl) thermometry (Holland and Blundy, 1994) were applied to the granitoid (AH barometry and hb-pl thermometry) and mafic metamorphic rocks (hb-pl thermometry) (see Appendix). For the magmatic 


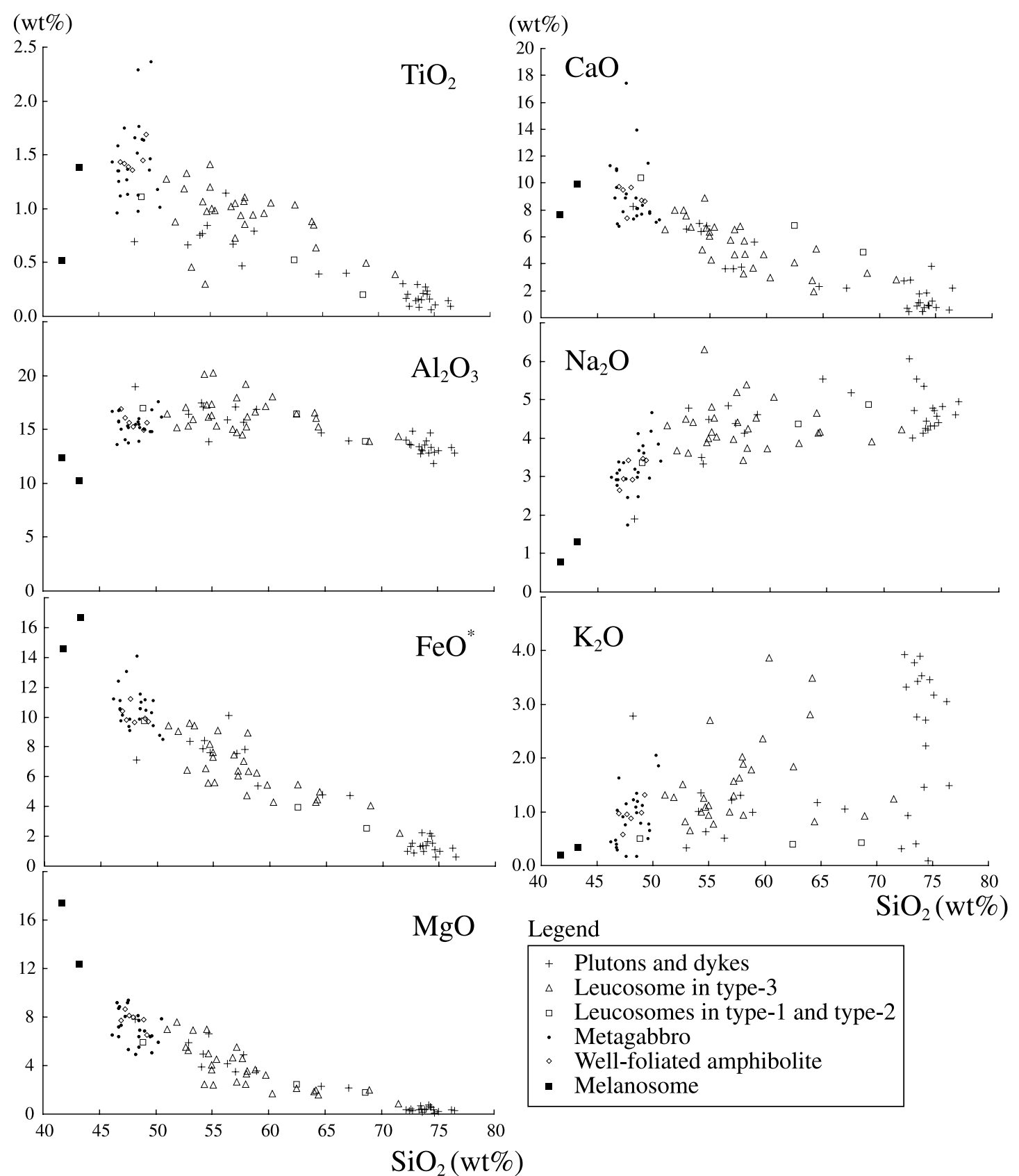

Figure 7. Harker diagrams of selected major elements for later intrusions, mafic metamorphic rocks and melanosomes from the Asago body.

amphiboles from the granitoid, $\mathrm{P}-\mathrm{T}$ conditions were estimated to be $\mathrm{P}=3.5-5.5 \mathrm{kbar}$ and $\mathrm{T}=690-760^{\circ} \mathrm{C}$, respectively. On the other hand, for the metamorphic amphiboles from mafic metamorphic rocks, $\mathrm{T}$ conditions of the granulite facies metagabbro and well-foliated amphibolite were estimated to be $850-860^{\circ} \mathrm{C}$ and $690-780^{\circ} \mathrm{C}$, respectively (Table 1). The conditions of the granulite facies metagabbro are high enough to cause the melting of the amphibolite (e.g. Johannes and Holtz, 1996) along with its dehydration.

\section{Partial melting process}

Johannes and Holtz (1996) postulated that partial melting of amphibolite yields melt fraction of tonalite or quartz dioritic composition. Melt yielded from the partial melting of amphibolite consists of quartzo-feldspathic minerals, and has tonalitic or quartz dioritic compositions. On the other hand, ferro-magnesian minerals, such as clinopyroxene, orthopyroxene, ilmenite, magnetite, hornblende and garnet, tend to remain as residua during partial melting. Among these minerals, only garnet occurs as a resid- 

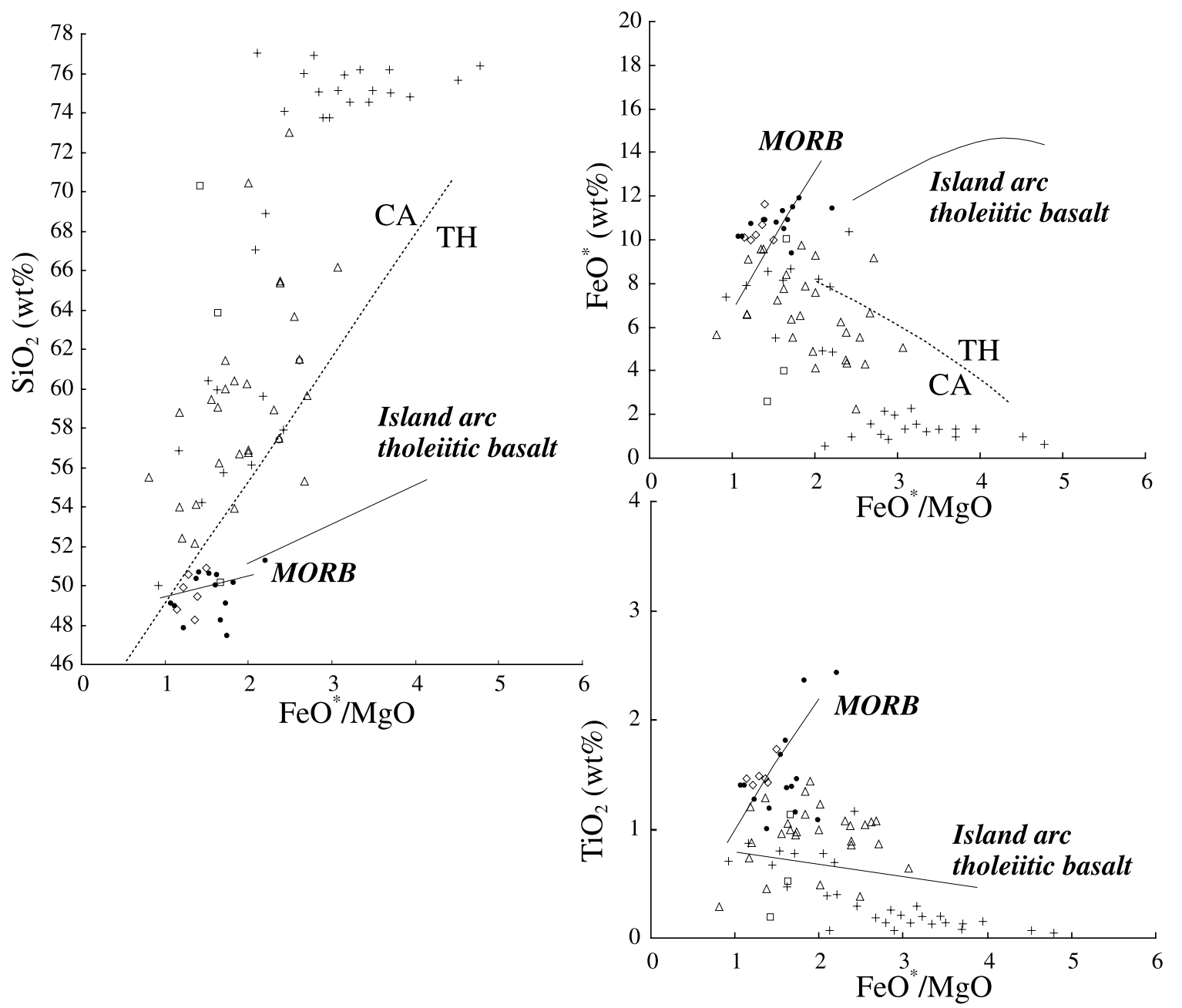

Figure 8. $\mathrm{SiO}_{2}, \mathrm{FeO}^{*}$ and $\mathrm{TiO}_{2}$ variation vs. $\mathrm{FeO}^{*} / \mathrm{MgO}$ ratio for later intrusions and mafic metamorphic rocks from the Asago body. Discrimination lines between calc-alkaline (CA) and tholeiite (TH), and variation line of mid-ocean-ridge-basalt (MORB) from Miyashiro (1975). Symbols are the same in Figure 7.

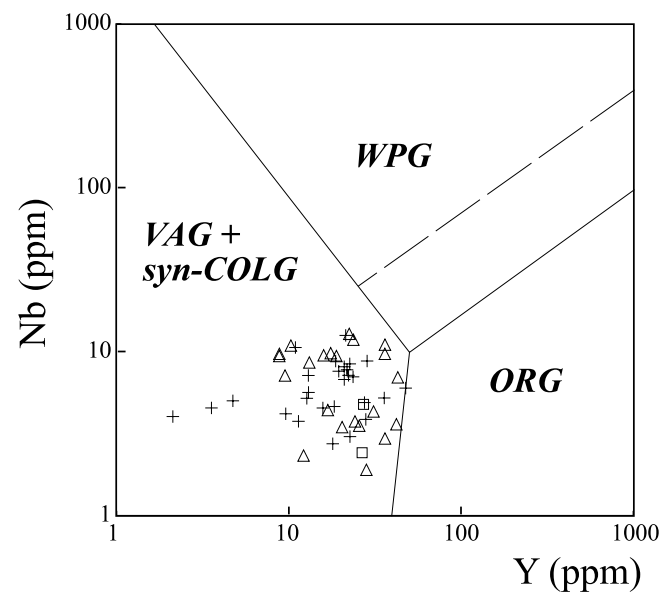

Figure 9. $\mathrm{Nb}$ vs. $\mathrm{Y}$ and $\mathrm{Rb}$ vs. $\mathrm{Y}+\mathrm{Nb}$ discrimination diagram for granitoids in different tectonic setting (Pearce et al., 1984), for granitoids in later intrusions suite from the Asago body. Abbreviations: VAG, volcanic arc granite; WPG, within-plate granites; ORG, ocean ridge granite; syn-COLG, syn-collisional granite. Symbols are the same in Figure 7. uum in conditions of more than $10 \mathrm{kbar}$. In the case of the Asago body, no garnet occurs in the migmatite, suggesting that the pressure conditions during anatexis were less than $10 \mathrm{kbar}$, which is consistent with the lower pressure (3.5-5.5 kbar) estimated from the chemistry of amphiboles, noted above.

Compositions of mafic metamorphic rocks, later intrusions and melanosomes are plotted on $\mathrm{FeO}^{*}-\mathrm{Al}_{2} \mathrm{O}_{3}{ }^{-}$ $\mathrm{MgO}$ ternary diagram (Fig. 11). In this plot, $\mathrm{FeO}^{*}$ and $\mathrm{MgO}$ apices can be considered as ferro-magnesian minerals join (i.e. residua). On the other hand, the $\mathrm{Al}_{2} \mathrm{O}_{3}$ apex can be considered as feldspar join (i.e. melt). In this ternary space, compositions of the mafic metamorphic rocks occupy the central domain, whereas those of later intrusions have a wide range and plot in the field toward $\mathrm{Al}_{2} \mathrm{O}_{3}$ apex (i.e. more enriched in $\mathrm{Al}_{2} \mathrm{O}_{3}$ and depleted in $\mathrm{FeO}^{*}$ and $\mathrm{MgO}$ ). On the other hand, melanosomes are more depleted in $\mathrm{Al}_{2} \mathrm{O}_{3}$ and more enriched in $\mathrm{FeO}^{*}$ and $\mathrm{MgO}$ 


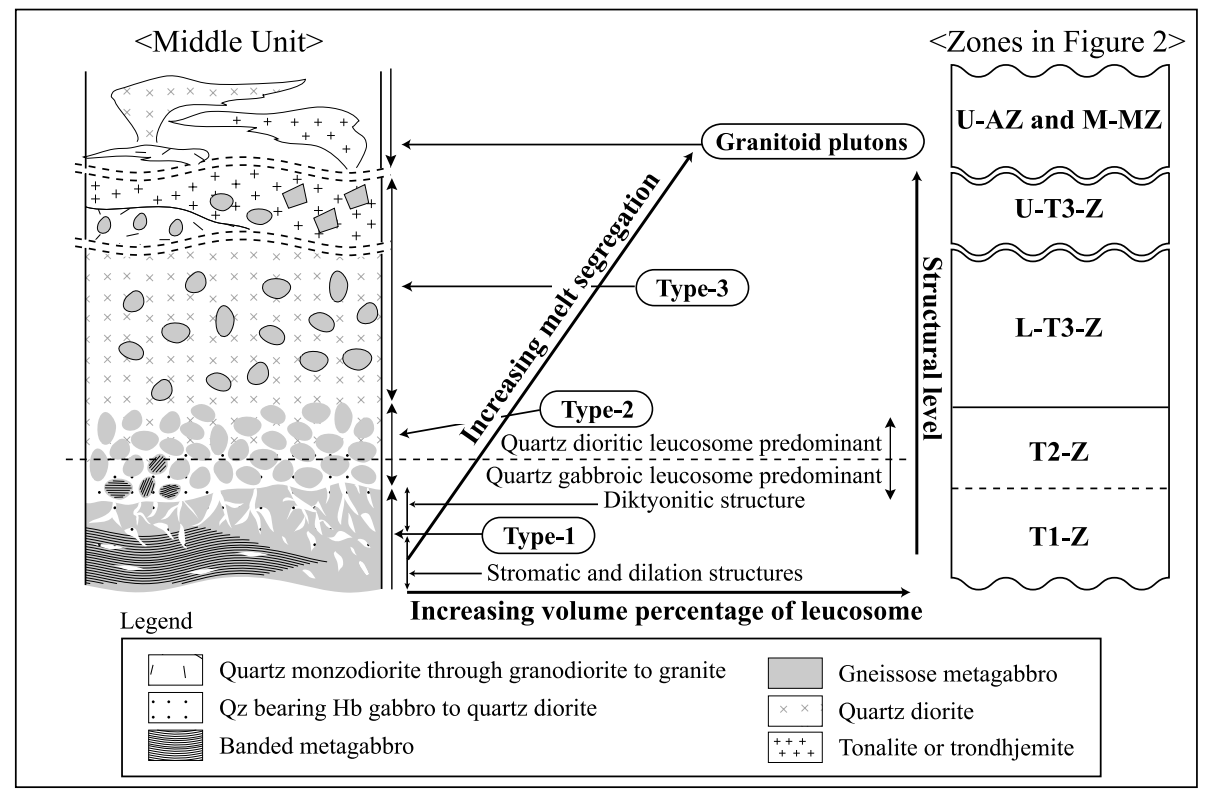

Figure 10. Schematic representation of the field relation between various types of migmatites and granitoid plutons (not in scale).

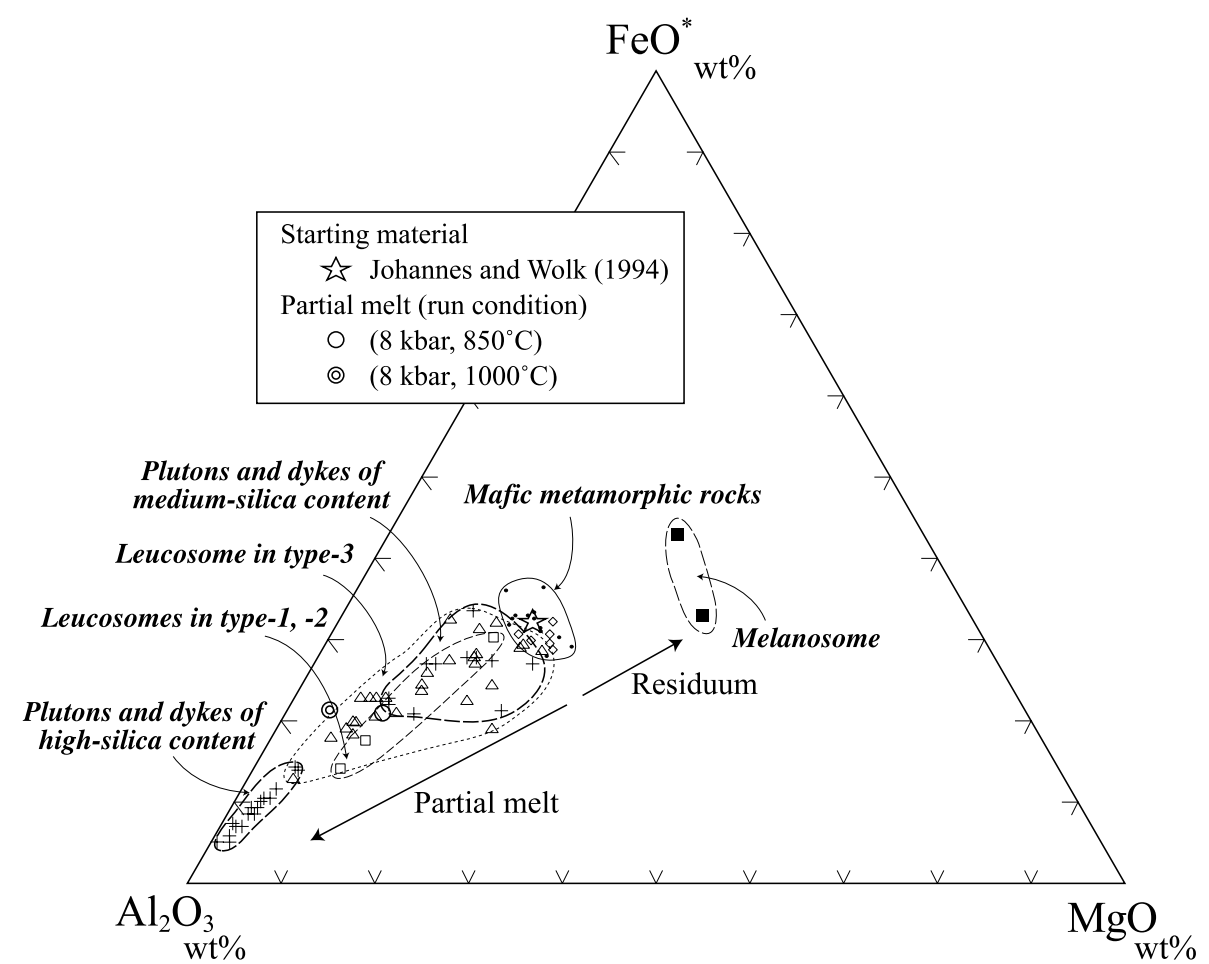

Figure 11. $\mathrm{FeO}^{*}-\mathrm{Al}_{2} \mathrm{O}_{3}-\mathrm{MgO}$ ternary diagram for later intrusions, mafic metamorphic rocks and melanosome from the Asago body together with the experimental data from Johannes and Wolk (1994). Symbols are the same in Figure 7.

contents than the mafic metamorphic rocks. Furthermore, compositional fields of the mafic metamorphic rocks, later intrusions and melanosome fall on almost a straight line. These results suggest that the change in chemistry of the respective rocks represent the partial melting processes. Thus, the later intrusions, which have similar composi- tions, were derived from the mafic metamorphic rocks (i.e. protolith of the migmatites), leaving the melanosomes as residuum. Partial melting experiments by Johannes and Wolk (1994) (data from Johannes and Holtz, 1996) support this result, where similar compositions of partial melt to those of later intrusions from this study area is derived 


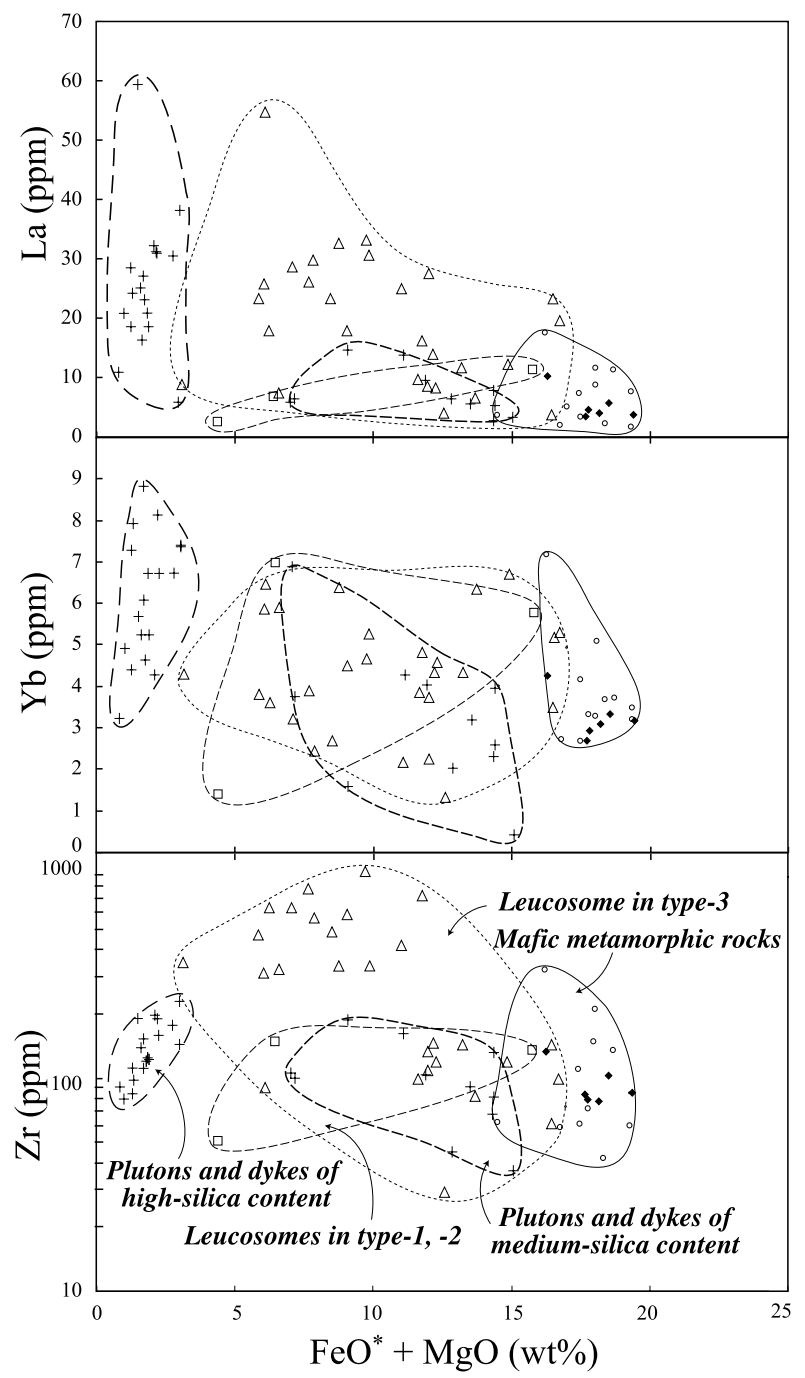

Figure 12. $\mathrm{La}, \mathrm{Yb}$ and $\mathrm{Zr}$ vs. $\left(\mathrm{FeO}^{*}+\mathrm{MgO}\right)$ variation diagram for later intrusions and mafic metamorphic rocks from the Asago body. Symbols are the same in Figure 7.

from melting of the starting material with the composition similar to those of the mafic metamorphic rocks.

\section{Magmatic evolution}

On the basis of field appearances and geochemical characteristics noted above, melt components of the later intrusions are divided into four suites: (1) leucosomes in type-1 and -2, (2) leucosome in type-3, (3) plutons and dykes of medium-silica content $\left(\mathrm{SiO}_{2}\right.$ 52-67 wt\%), (4) plutons and dykes of high-silica content $\left(\mathrm{SiO}_{2} 72-76\right.$ wt $\%)$. Figure 12 shows variations of $\mathrm{La}, \mathrm{Yb}$ and $\mathrm{Zr}$ against $\left(\mathrm{FeO}^{*}+\mathrm{MgO}\right)$ content. $\left(\mathrm{FeO}^{*}+\mathrm{MgO}\right)$ content reflects a proportion of mafic minerals. These diagrams show that the compositional field of the leucosome in type -3 is quite large, which includes most of the fields of leucosomes in type-1 and -2 , and plutons and dykes of medium-silica content, but excludes most of the field of those of high-silica content. The leucosomes in type-1 and -2 have relatively lower $\mathrm{La}$ and $\mathrm{Zr}$ contents than the leucosomes in type- 3 , although the whole field of respective leucosomes overlap. Based on the $\mathrm{FeO}^{*}-\mathrm{Al}_{2} \mathrm{O}_{3}-\mathrm{MgO}$ ternary diagram (Fig. 11), and on the Harker diagrams of $\mathrm{TiO}_{2}, \mathrm{Al}_{2} \mathrm{O}_{3}, \mathrm{FeO}^{*}, \mathrm{MgO}, \mathrm{CaO}, \mathrm{Na}_{2} \mathrm{O}$ and $\mathrm{K}_{2} \mathrm{O}$ versus $\mathrm{SiO}_{2}$ (Fig. 7), the compositional field of the plutons and dykes of high-silica content is isolated from those of the others suites. As noted above, the melts in type- 3 that derived from the type- 1 or -2 have a wide range of compositions. Some leucosomes in type -3 may have been a source for the plutons and dykes of medium-silica content. However, to form the plutons and dykes of high-silica content, different processes are needed. Therefore, it can be assumed that only the plutons and dykes of highsilica content were derived from compositionally more differentiated magma from the leucosomes. However, there is no indication of such compositional overlap, and hence it is possible that the plutons and dykes of high-silica content originated from a completely exotic magma, an aspect which remains to be investigated in future studies.

\section{Conclusions}

1. The middle to lower crustal section of an intra-oceanic island arc is exposed in the M-Unit of the Asago body, which consists mainly of mafic metamorphic rocks of MORB-like affinity and felsic to mafic later intrusions of island arc affinity. Mafic migmatite develops in the lowermost horizon of this section, where the mafic metamorphic rocks have a mineral paragenesis of granulite facies metamorphism.

2. Morphological changes of migmatite structures with increasing structural level suggest that melt formed at the lowermost part (type-1), gradually separated from the protolith (type-2), and finally formed melt-enriched magma reservoirs (type-3). The melt segregation further proceeded upwards, which led to the formation of plutons and dykes of later intrusions in the middle to upper horizon of the M-Unit.

3. Bulk rock chemistry suggests that the later intrusions were derived from the partial melting of the mafic metamorphic rocks, leaving the melanosome as residuum. The leucosomes in migmatite became a source of the plutons and dykes of medium-silica content, whereas chemical compositions of the plutons and dykes of high-silica content and those of the leucosomes do not overlap. This fact may indicate that the plutons and dykes of high-silica content formed by a different process than the other 
suites.

\section{Acknowledgments}

I am very grateful to T. Takeshita for his advice, discussion and improving the manuscript, and I am grateful to Y. Hayasaka for all help and advice throughout this research work in the Asago body. I would also like to thank M. Arima, E.W. Sawyer, T. Kawakami and A. EL. Fakharani for helpful comments on the manuscript, and Y. Shibata, the Natural Science Center for Basic Research and Development (N-BARD), Hiroshima University, for technical assistance. An earlier versions the manuscript was reviewed and improved by M. Santosh and T. Tsujimori.

\section{References}

Anderson, J.L. and Smith, D.R. (1995) The effects of temperature and $f_{\mathrm{O}_{2}}$ on the $\mathrm{Al}$-in-hornblende barometer. American Mineralogist, 80, 549-559.

Atherton, M.P. and Petford, N. (1993) Generation of sodium-rich magmas from newly underplated basaltic crust. Nature, 362, 144-146.

Beard, J.S. (1995) Experimental, geological, and geochemical constraints on the origin of low-K silicic magmas in oceanic arc. Journal of Geophysical Research, 100, 15593-15600.

Beard, J.S., and Lofgren, G.E. (1991) Dehydration melting and water-saturated melting of basaltic and andesitic greenstones and amphibolites at 1,3 and $6.9 \mathrm{~kb}$. Journal of Petrology, 32, 365-401.

Brown, M. (1973) The definition of metatexis, diatexis and migmatite. Proceeding of the Geologists' Association, 84, 371382.

Defant, M.J. and Drummond, M.S. (1990) Derivation of some modern arc magmas by melting of young subducted lithosphere. Nature, 347, 662-665.

Drummond, M.S., Defant, M.J. and Kepezhinskas, P.K. (1996) Petrogenesis of slab-derived trondhjemite-tonalite-daciteadakite magmas. Transactions of Royal Society of Edinburgh: Earth Sciences, 87, 205-215.

Haraguch, S., Ishii, T., Kimura, J. and Ohara, Y. (2003) Formation of tonalite from basaltic magma at the Komahashi-Dani Seamount, northern Kyushu-Palau Ridge in the Philippine Sea, and growth of Izu-Ogasawara (Bonin)-Mariana arc crust. Contributions to Mineralogy and Petrology, 145, 151-168.

Hayasaka, Y. (1990) Maizuru Terrane, In Pre-Cretaceous Terrane of Japan (Ichikawa, K., Mizutani, S., Hara, I., Hada, S. and Yao, A. Eds.). pp. 413. Publication of IGCP 244, Nihon-Insatsu, Osaka, 81-95.

Hayasaka, Y., Ikeda, K., Shishido, T. and Ishizuka, M. (1996) Geological reconstruction of the Maizuru Terrane as an arcback arc system. In Tectonics and Metamorphism (The Hara Volume) (T., Hayasaka, Y., Shiota, T., Oda, M., Takeshita, T., Yokoyama, S. and Ohotomo, Y. Eds). pp. 403, Soubun, Tokyo, 134-144.

Herzig, C.T., Kimbrough, D.L. and Hayasaka, Y. (1997) Early Permian zircon uranium-lead ages for plagiogranites in the Yakuno ophiolite, Asago district, Southwest Japan. The Island Arc, 6, 396-403.
Holland, T. and Blundy J. (1994) Non-ideal interactions in calcic amphiboles and their bearing on amphibole-plagioclase thermometry. Contributions to Mineralogy and Petrology, 116, 433-447.

Ichiyama, Y. and Ishiwatari, A. (2003) Petrochemical evidence for off-ridge magmatism in a back-arc setting from the Yakuno ophiolite, Japan. The Island Arc, 13, 157-177.

Ishiwatari, A., Ikeda, Y. and Koide, Y. (1990) The Yakuno ophiolite, Japan: fragments of Permian island arc and marginal basin crust with the hotspot. In Proceedings, Symposium of Troodos 1987, Ophiolite: Oceanic Crust Analogues (Malpas, J. P., Moores, E. M., Panayiotou A. and Xenophontos, C. Eds.). pp. 733, Geological Survey Department, Nicosia, Cyprus, $476-506$.

Ishiwatari, A. (1985) Granulite-facies metacumulates of the Yakuno ophiolite, Japan: evidence for unusually thick oceanic crust. Journal of Petrology, 26, 1-30.

Ishiwatari, A. (1999) Fragment of Paleozoic oceanic island arc crust in the Inner Zone of southwest Japan: the Kamigori metagabbro body, Hyogo Prefecture. In Ophiolite and tectonics of accretionary complex (Miyashita, S., Arai, S., Kiminami, K. and Matsuoka, A. Eds.). pp. 316, Geological Society of Japan Memoir, 52, 273-285.

Johannes, W. and Holtz, F. (1996) Formation of Granitic Magmas by Dehydration Melting. In Petrogenesis and experimental petrology of granitic rocks (Johannes, W. and Holtz, F. Eds.). pp. 335, Springer-Verlag. Berlin, 264-301.

Kawate, S. and Arima, M. (1998) Petrogenesis of the Tanzawa plutonic complex, central Japan: exposed felsic meddle crust of the Izu-Bonin-Mariana arc. The Island Arc, 7, 342-358.

Kay, R.W. and Kay, S.M. (1988) Crustal recycling and the Aleutian arc. Geochimica et Cosmochimica Acta, 52, 1351-1359.

Koide, Y. (1986) Origin of the Ibara metabasalts from the Maizuru Tectonic Belt, southwest Japan: Journal of the Geological Society of Japan, 92, 329-348.

Koide, T., Tazaki, K. and Kagami, H. (1987) Sr isotopic study of Ibara dismembered ophiolite from the Maizuru Tectonic Belt, southwest Japan: Journal of Japanese Association Mineralogy, Petrology and Economic Geology, 82, 1-15.

Leake, B.E., Woolley, A.R., Arps, C.E.S., Birch, W.D., Gilbert, M.C., Grice, J.D., Hawthorne, F.C., Kato, A., Kisch, H.J., Krivovichev, V.G., Linthout, K., Lard, J. and Mandarino, J. (1997) Nomenclature of amphiboles: report of the subcommittee of the international mineralogical association, commission on new minerals and mineral names. Mineralogical Magazine, 61, 295-321.

Martin, H. (1986) Effect of steeper Archean geothermal gradient on geochemistry subduction-zone magmas. Geology, 14, 753-756.

Martin, H. (1987) Petrogenesis of Archean trondhjemite, tonalites, and granodiorites from eastern Finland: major and trace element geochemistry. Journal of Petrology, 28, 921-953.

Martin, H. (1993) The mechanisms of petrogenesis of the Archaean continental crust: comparison with modern processes. Lithos, 30, 373-388.

Meijer, A. (1983) The origin of low-K rhyolites from the Mariana frontal arc. Contributions to Mineralogy and Petrology, 83, 45-51.

Mehnert, K.R. (1968) Migmatites and the origin of granitic rocks. In Megascopic structures of migmatite (Mehnert, K.R. Ed.). pp. 405, Elsevier, Amsterdam, 7-42.

Milord, I., Sawyer, E.W. and Brown, M. (2001) Formation of dia- 
texite migmatite and granite magma during anatexis of semipelitic metasedimentary rocks: an example from St. Malo, France. Journal of Petrology, 42, 487-505.

Miyashiro, A. (1975) Classification, characteristics, and origin of ophiolites. Journal of Geology, 83, 249-281.

Nakajima, K. and Arima, M. (1998) Melting experiments on hydrous low-K tholeiite: implications for the genesis of tonalitic crust in the Izu-Bonin-Mariana arc. The Island Arc, 7, 359-373.

Nelson E.P. and Forsythe, R.D. (1989) Ridge collision at convergent margins: implications for Archean and post-Archean crustal growth. Tectonophysics, 161, 307-315.

Platt, J.P. and Vissers, R.L.M. (1980) Extensional structures in anisotropic rocks. Journal of Structural Geology, 2, 397-410.

Pearce, J.A., Harris, N.B.W. and Tindle, A.G. (1984) Trace element discrimination diagram for the tectonic interpretation of granitic rocks. Journal of Petrology, 24, 956-983.

Sawyer, E.W. (1991) Disequilibrium melting and the rate of melt -residuum separation during migmatization of mafic rocks from the Grenville Front, Quebec. Journal of Petrology, 32, 701-738.

Sawyer, E.W. (1996) Melt segregation and magma flow in migmatites: implications for the generation of granite magmas. Transactions of the Royal Society of Edinburgh: Earth Sciences, 87, 85-94.

Schmidt, M.W. (1992) Amphibole composition in tonalite as a function of pressure: an experimental calibration of the $\mathrm{Al}$-in -hornblende barometer. Contributions to Mineralogy and Petrology, 110, 304-310.

Shirey, S.B. and Hanson, G.N. (1984) Mantle-derived Archean monzodiorites and trachyandesites. Nature, 310, 222-224.

Stern, R.A. and Hanson, G.N. (1991) Archean high-Mg granodiorite: a derivative of light rare earth element-enriched monzodiorite of mantle origin. Journal of Petrology, 32, 201238.

Taira, A., Pickering, K.T., Windley, B.F. and Soh, W. (1992) Accretion of Japanese island arcs and implications for the origin of Archean greenstone belts. Tectonics, 11, 1224-1244.

Wilson, M (1989) Mid-ocean ridge. In Igneous petrogenesis (Wilson, M. Ed.). pp. 466, Chapman \& Hall. London, 101149.

Wolf, M.B. and Willie, P.J., 1994, Dehydration-melting of amphibolite at $10 \mathrm{kbar}$ : The effects of temperature and time. Contributions to Mineralogy and Petrology, 115, 369-83.

Wimmenauer, W. and Bryhni, I. (2002) Migmatites and related rocks. 6, Towards a unified nomenclature of metamorphic petrology. A proposal on behalf of the IUGS Subcommission on the Systematics of Metamorphic Rocks, Provisional version on SCMR website.

\section{Appendix}

The following equations have been used to estimate the temperature and pressure conditions of crystallization of magmatic amphiboles from granitoid. Equation $\left(P_{\mathrm{S}}\right.$, eq. 1) of Schmidt (1992) is substituted for the value of pressure $(P)$ in edenite-tremolite thermometer $\left(T_{\mathrm{A}}\right.$, eq. 2$)$ by Holland and Blundy (1994). This thermometry is substituted into the temperature dependent barometer $\left(P_{\mathrm{AS}}\right.$, eq3 ) of Anderson and Smith (1995). $\mathrm{Al}^{\text {total }}$ is the total Al content of hornblende in atoms per formula unit. $\mathrm{R}=$ $0.0083144 \mathrm{kJK}^{-1} \mathrm{~mol}^{-1}, Y_{\mathrm{ab}}=0$ for $X_{\mathrm{ab}}^{\mathrm{plag}}>0.5$ or else $Y_{\mathrm{ab}}=$ $12.0 \times\left(1-X_{\mathrm{ab}}^{\mathrm{plag}}\right)^{2}-3.0 \mathrm{~kJ}$, and various $X$ terms are defined following Holland and Blundy (1994).

$$
\begin{aligned}
& P_{\mathrm{S}}( \pm 0.6 \mathrm{kbar})=-3.01+4.76 \mathrm{Al}^{\text {total }} \\
& T_{\mathrm{A}}\left( \pm 40^{\circ} \mathrm{C}\right)+273=\left\{-76.95+0.79 P+Y_{\mathrm{ab}}\right. \\
& \left.\quad+39.4 X_{\mathrm{Na}}^{\mathrm{A}}+22.4 X_{\mathrm{K}}^{\mathrm{A}}+(41.5-2.89 P) \cdot X_{\mathrm{A}}^{\mathrm{M} 2}\right\} \\
& \quad /\left[-0.0650-\mathrm{R} \cdot \ln \left\{\left(27 \cdot X_{\square}^{\mathrm{A}} X_{\mathrm{Si}}^{\mathrm{T} 1} \cdot X_{\mathrm{ab}}^{\mathrm{plag}}\right)\right.\right. \\
& \left.\left.\quad /\left(256 \cdot X_{\mathrm{Na}}^{\mathrm{A}} \cdot T_{\mathrm{Al}}^{\mathrm{T} 1}\right)\right\}\right] \\
& P_{\mathrm{AS}}( \pm 0.6 \mathrm{kbar})=4.76 \mathrm{Al}^{\mathrm{total}}-3.01 \\
& \quad-\left\{\left(T_{\mathrm{A}}-675\right) / 85\right\} \cdot\left\{0.530 \mathrm{Al}^{\text {total }}\right. \\
& \left.\quad+0.005294\left(T_{\mathrm{A}}-675\right)\right\}
\end{aligned}
$$

On the other hand, the following edenite-richterite thermometer $\left(T_{\mathrm{B}}\right.$, eq-4) by Holland and Blundy (1994) have been used to estimate the temperature conditions of recrystallization of metamorphic amphiboles from mafic metamorphic rocks. The mean pressure condition estimated from magmatic amphiboles $(4.5 \mathrm{kbar})$ is substituted for the value of pressure $(P)$ in the following thermometry.

$$
\begin{gathered}
T_{\mathrm{B}}\left( \pm 40^{\circ} \mathrm{C}\right)+273=\left\{78.44+Y_{\mathrm{ab}^{-} \mathrm{an}}-33.6 X_{\mathrm{Na}}^{\mathrm{M} 4}\right. \\
\left.-(66.8-2.92 \mathrm{P}) \cdot X_{\mathrm{Al}}^{\mathrm{M} 2}+78.5 X_{\mathrm{Al}}^{\mathrm{T} 1}+9.4 X_{\mathrm{Ms}}^{\mathrm{A}}\right\} \\
/\left[0.0721-\mathrm{R} \cdot \ln \left\{\left(27 \cdot X_{\mathrm{Na}}^{\mathrm{M} 4} \cdot X_{\mathrm{Si}}^{\mathrm{T} 1} \cdot X_{\mathrm{an}}^{\mathrm{plag}}\right)\right.\right. \\
\left.\left./\left(64 \cdot X_{\mathrm{Ca}}^{\mathrm{M} 4} \cdot X_{\mathrm{Al}}^{\mathrm{T} 1} \cdot X_{\mathrm{ab}}^{\mathrm{plag}}\right)\right\}\right]
\end{gathered}
$$

(Manuscript received; 4 January, 2004)

(Manuscript accepted; 5 May, 2004) 